\title{
Taxonomy and ecology of the Family Cytheruridae (Ostracoda) in Recent sediments from the northern Rio de Janeiro coast, Brazil
}

\author{
MARIA INES FEIJO RAMOS ${ }^{1,2}$, JOAO CARLOS COIMBRA ${ }^{1}$, ROBIN C. WHATLEY ${ }^{2}$ \& ALICIA MOGUILEVSKY ${ }^{2}$ \\ ${ }^{1}$ Instituto de Geociências, UFRGS, Caixa Postal 15001, CEP 91501-970, Porto Alegre, RS, Brazil. email: RAMOS@if1.UFRGS.BR; \\ COIMBRA@if1.UFRGS.BR \\ ${ }^{2}$ Institute of Earth Studies, University of Wales, Aberystwyth SY23 3DB, UK. email: RCW@ABER.AC.UK: ALM@ABER.AC.UK
}

\begin{abstract}
A study of the family Cytheruridae in Recent sediments from the coast of northern Rio de Janeiro State revealed the presence of four new species: (Hemicytherura auriculata, Oculocytheropteron delicatum, Oculocytheropteron circumcostatum and Semicytherura caudata,) and four previously described species (Semicytherura rugosoreticulata Whatley, Chadwick, Coxill \& Toy, 1988, Oculocytheropteron macropunctatum Whatley, Chadwick, Coxill \& Toy, 1988, Oculocytheropteron reticulopunctatum Whatley, Chadwick, Coxill \& Toy, 1988 and Paracytheridea bulbosa Purper \& Ornellas, 1989). A further two species Cytheropteron sp. and Kangarina sp. are left in open nomenclature due to paucity of the material. The ecology and distribution of the fauna suggest that the presence of many of these species, which also occur in colder waters off the coast of Uruguay and Argentina, is probably due to the upwelling of the South Atlantic Central Water in this area. J. Micropalaeontol. 18(1): 1-16, June, 1999.
\end{abstract}

\section{INTRODUCTION}

The cytherurids are one of the most diverse and abundant families of cytheracean marine and brackish water Ostracoda. Their diversity in either shallow or deep water changes little from the poles to the equator and, in addition, they commonly represent one of the most abundant families. One of the characteristics of the Cytheruridae is their small size but, because they frequently have very species-specific ornamentation, they are easily recognized. Notwithstanding this, they are often left in open nomenclature or dealt with solely at the generic level.

In Brazil, only Ornellas \& Fallavena (1978) and Purper \& Ornellas (1987a, b; 1989) have made detailed specific studies of cytherurids. The former workers described a new species, Cytherura purperae, a mixohaline species from southern Brazil, while Purper \& Ornellas (1987a, b; 1989) studied the taxonomy and zoogeography of the genus Paracytheridea along the Brazilian coast. Dias-Brito et al. (1988) and Coimbra et al. (1992) studied Sepetiba and Tamandare Bays, respectively, and recorded the occurrence of cytherurids. Pinto et al. (1978) also surveyed the Ostracoda along the Brazilian coast, including the cytherurids. Whatley et al. (1988) monographed the Cytheruridae from the Antarctic to southern Brazil and described a total of 34 species belonging to eight genera.

This paper deals with the taxonomy and ecology of the entire cytherurid fauna present in a specific geographical area of the Brazilian coast. The northern coast of Rio de Janeiro State was chosen because it records the greatest intensity of upwelling of cold water masses from the south. This area coincides with the southern portion of the zoogeographical 'transition zone' of the ostracod fauna of the Brazilian continental shelf as defined by Coimbra \& Ornellas (1989).

\section{MATERIAL AND METHODS}

The 47 samples studied were collected during the GEOCOSTA RIO II expedition and were made available to the authors by the Department of Geography of the Universidade Federal do Rio de Janeiro, where the project 'Levantamento Físico Ambiental da Plataforma Continental Interna entre as cidades do Rio de Janeiro e Cabo Frio' was developed.

The samples were collected in March 1986. All the ostracods were picked from dry sediment samples, each weighing $20 \mathrm{~g}$, and mounted using conventional micropalaeontological techniques.

The constancy $(C)$ of the species (the frequency of the species in the samples, expressed as a percentage) was calculated using the following formula: $C=p \cdot 100 / P$, where $p=$ number of samples in which the species occurs and $P=$ total number of analysed samples. Dominance $(D)$ was calculated using the formula $D=t \cdot 100 / T$, where $t=$ number of total specimens of each species and $T=$ total number of specimens (Tinoco, 1989).

The diversity index was calculated using the Shannon-Wiener information function. The diversity index is expressed by the equation $H(S)=-\Sigma$ pi. $\ln p_{i}$, where $p_{i}=$ the proportion of each species $i$ and $\ln p_{i}=$ natural logarithm of $p_{i}$.

The percentage of sediment types in each water depth interval was calculated using the 'Idrisis' program for Windows.

The type material, together with a series of homotypes and hypotypes, is deposited at the Museu de Paleontologia da Universidade Federal do Rio Grande do Sul, Porto Alegre, UFRGS, under numbers MP-O-1483 to MP-O-1503 and MP-01462, MP-0-1463.

\section{STUDY AREA}

A rectangular area $(35 \times 15 \mathrm{~km})$ with depths ranging from 20 to $75 \mathrm{~m}$, of the continental shelf of Rio de Janeiro State, between Cabo Frio Island and Saquarema Lagoon $\left(22^{\circ} 55^{\prime} \mathrm{S}-23^{\circ} 05^{\prime} \mathrm{S}\right.$ and $42^{\circ} 00^{\prime} \mathrm{W}-42^{\circ} 20^{\prime} \mathrm{W}$ ), was studied. This area is about $80 \mathrm{~m}$ north of the city of Rio de Janeiro, immediately offshore of Lagoon Araruama (Fig. 1).

\section{Sedimentology}

Mainly relict sands, resulting from the lack of input of continental sediments and the presence of a barrier beach, cover 


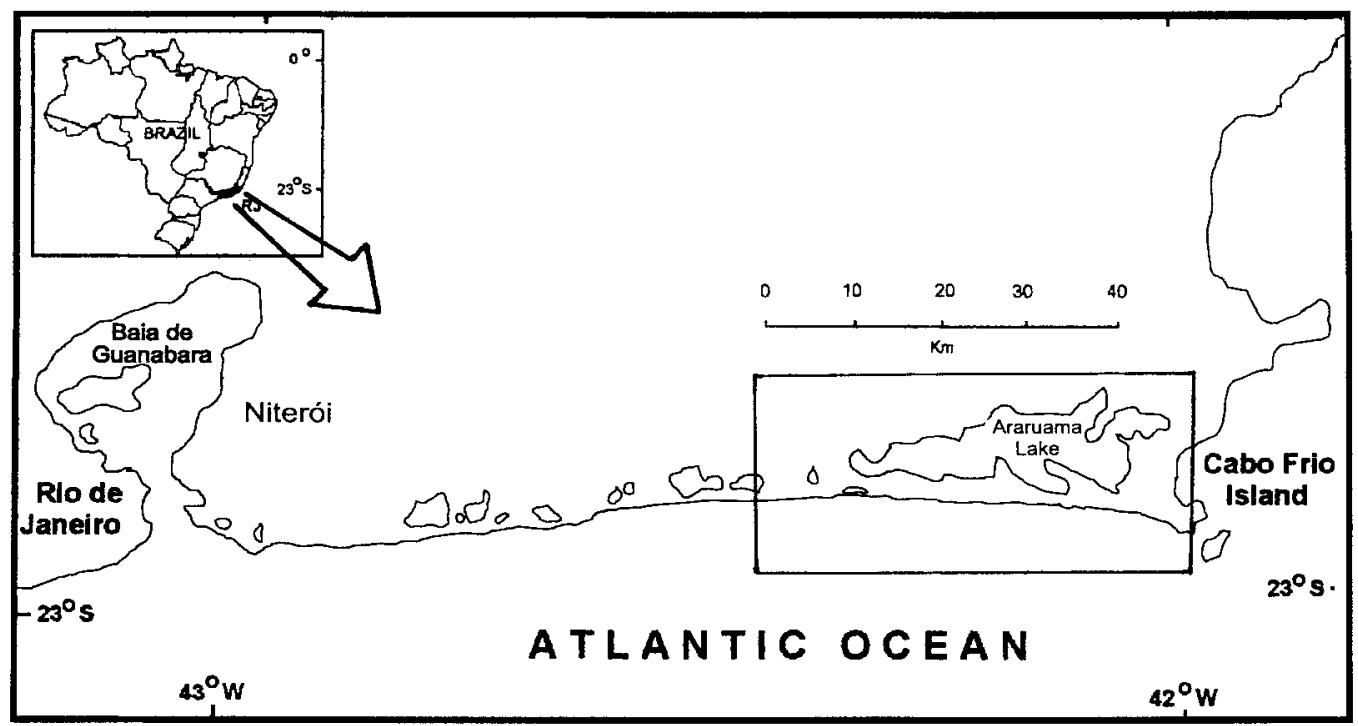

Fig. 1. Location of the study area.

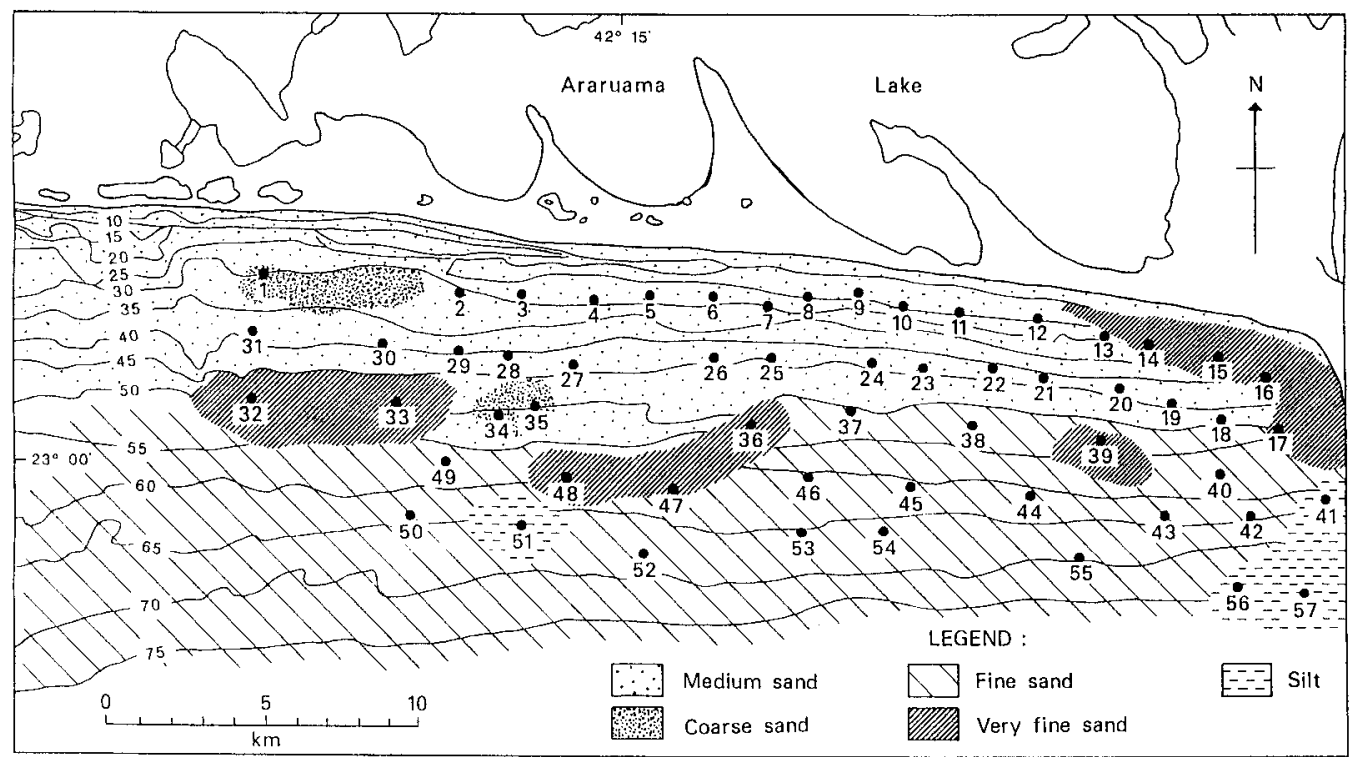

Fig. 2. Location of samples and distribution of bottom sediment types.

the study area. The erosion of the unfossiliferous Barreiras Group (Plio/Pleistocene) from alluvial deposits and sediments produces the relict sands. These sands are also the result of reworking by waves and currents. Grain size analysis shows a decreasing gradient both towards the east and towards deeper waters. Between the coast and a depth of $50 \mathrm{~m}$, medium sand predominates $(80 \%)$; an exception is in the far east of this area, near the town of Arraial do Cabo, where very fine sand predominates $(15 \%)$ within this depth range. Coarse sands occur in the west of the area and in isolated parts of the more central portion of the studied area. At depths greater than $50 \mathrm{~m}$, fine sand predominates. Very fine sand occurs in the western, central and eastern areas, but only in isolated patches between 60 and $70 \mathrm{~m}$ depth. Silt-grade sediments occur in the far southeast and also in a single sample from the central portion of this area, always at depths greater than $65 \mathrm{~m}$ (Figs. 2-9).

\section{Physical oceanography}

The main water masses affecting the area of study are: coastal water with temperatures $>18^{\circ} \mathrm{C}$ and salinities $<35 \%$; South Atlantic Central Water with temperatures between 6 and $18^{\circ}$ and salinities between 34.6 and $35.8 \%$; and Surface Tropical 

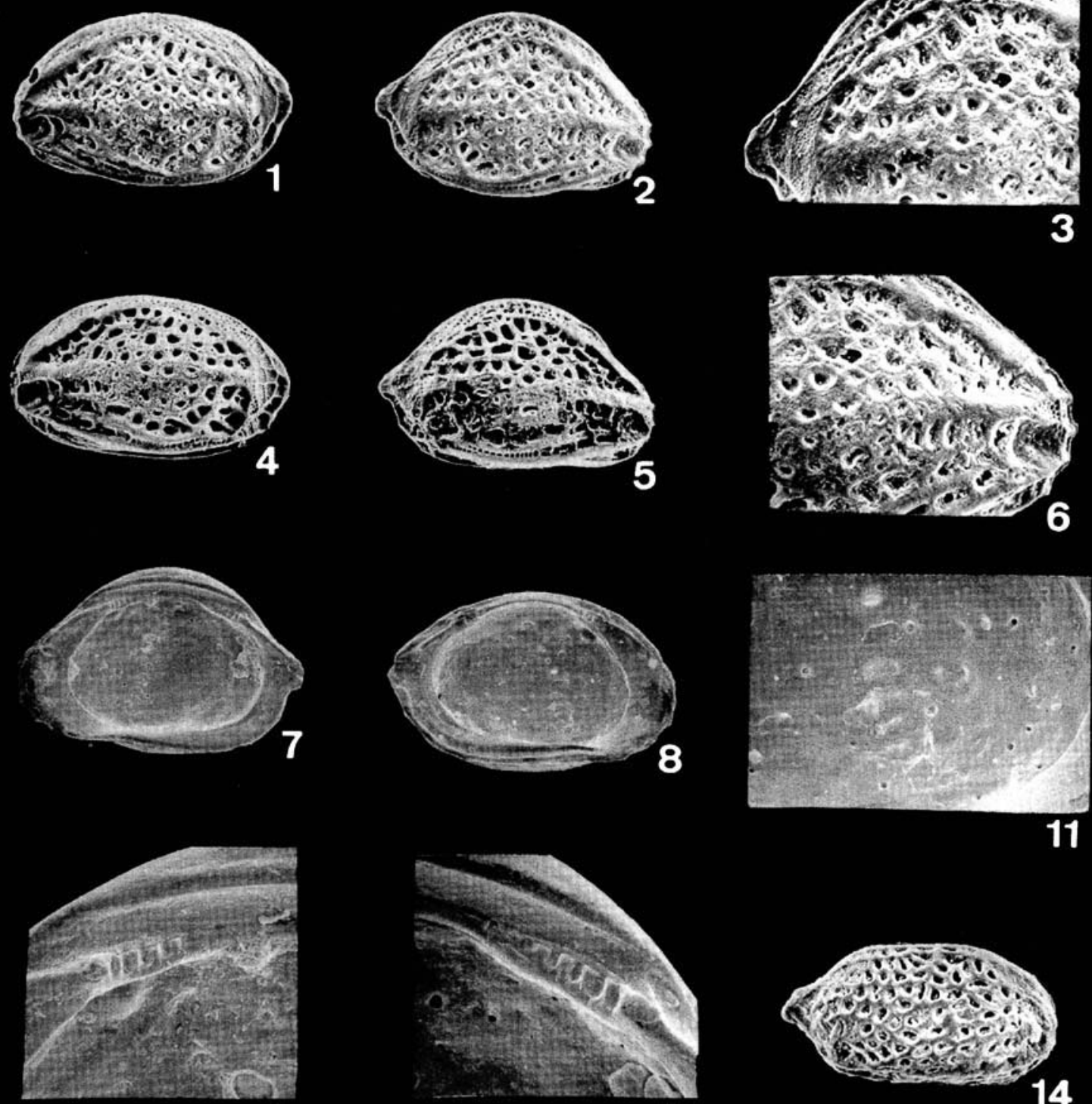

9

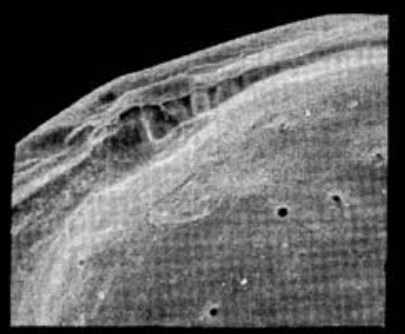

12
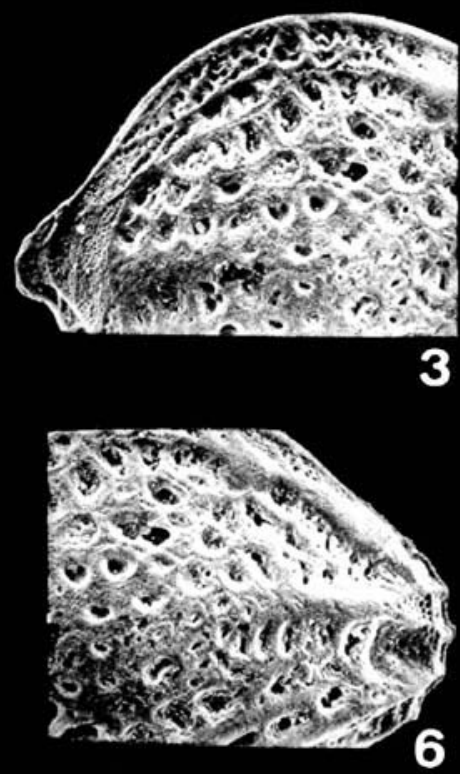

6

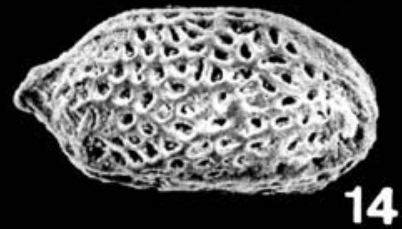

10

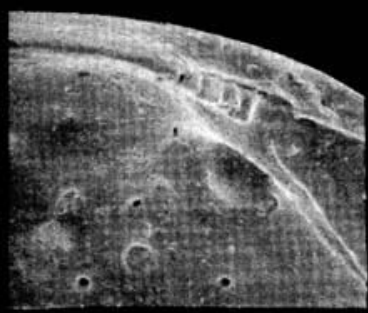

13

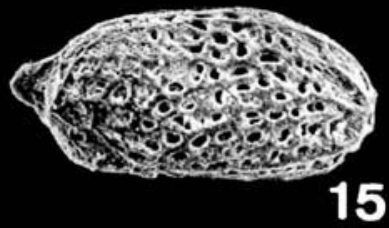

Explanation of Plate 1

figs 1-13. Hemicytherura auriculata sp. nov. figs 1-3, 6-13. Holotype. MP-O-1490. fig. 1. LV, external view, $\times 68$. fig. 2. RV, external view, $\times 68$. fig. 3. RV, Detail of postero-dorsal region, $\times 124$. fig. 4. Paratype. MP-O-1491. LV, External view, $\times 76$. fig. 5. Paratype. MP-O-1492, RV, external view, $\times 76$. fig. 6. Holotype. RV detail of anterior region, $\times 124$. fig. 7. Holotype. RV, internal view, $\times 85$. fig. 8. Holotype. LV, internal view, $\times 74$. fig. 9 . Holotype. RV, internal view, detail of anterior hinge, $\times 267$. fig. 10. Holotype. RV, internal view, detail of posterior hinge, $\times 318$, fig. 11. Holotype $\mathrm{LV}$, internal view, detail of muscle scar, $\times 228$. fig. 12. Holotype. $L V$, internal view, detail of posterior hinge, $\times 246$. fig. 13. Holotype. LV, internal view, detail of anterior hinge, $\times 219$. figs 14, 15. Semicytherura rugosoreticulata Whatley, Chadwick, Coxill \& Toy, 1988. fig. 14. Homotype. MP-O1500, female, RV, external view, $\times 77$. fig. 15. Homotype. MP-O-1501, male, RV, external view, $\times 74$. 


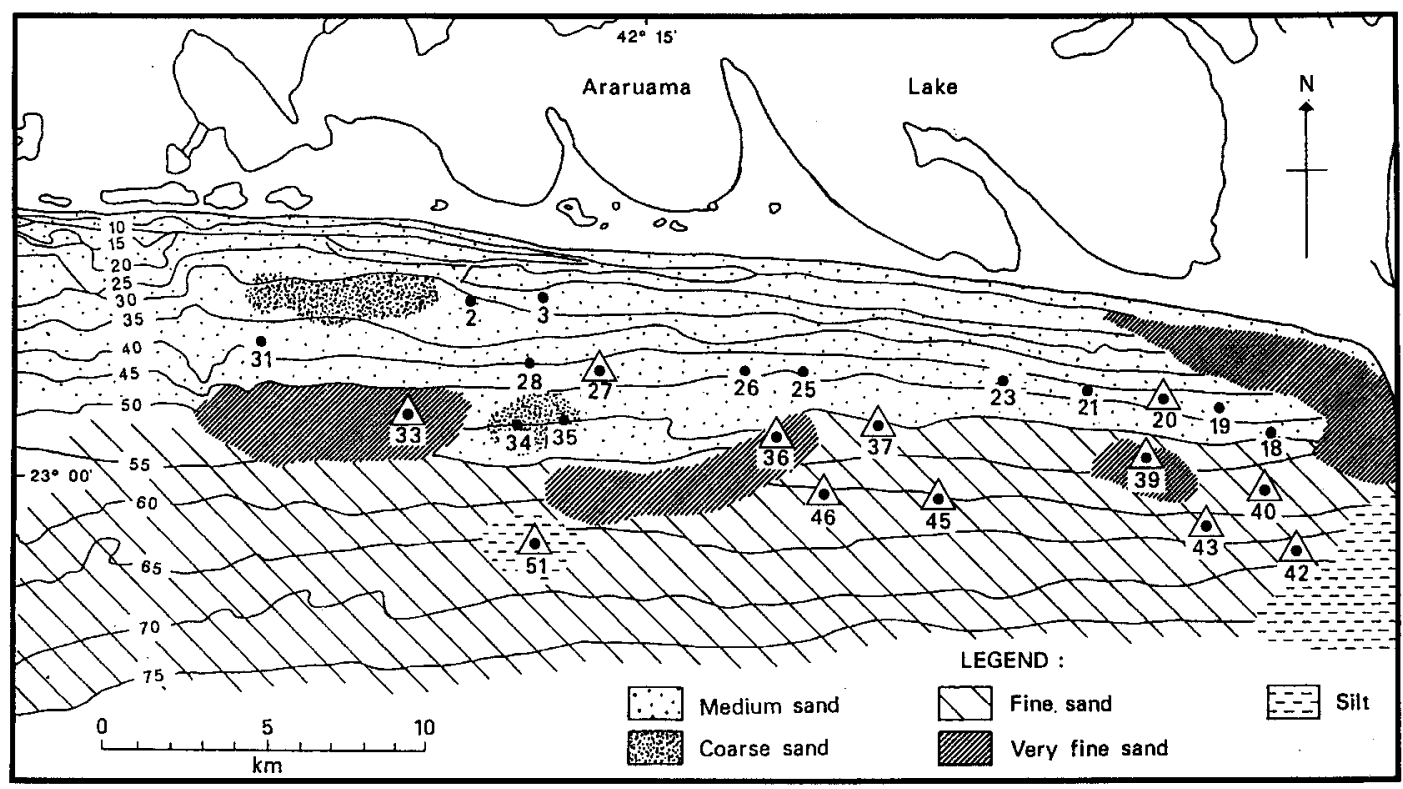

Fig. 3. Distribution of Oculocytheropteron delicatum sp. nov. and Hemicytherura auriculata sp. nov. $\triangle$ Occurrence of $O$. delicatum only. $\bullet$, Occurrence of both $O$. delicatum and $H$. auriculata.

Water with temperatures $>18^{\circ} \mathrm{C}$ and a salinity $>35.9 \%$. The Coastal Water results from the mixing of water coming from the continental drainage of superficial tropical water and of South Atlantic Central Water. The South Atlantic Central Water is produced by a mixture of Tropical Water and Subantarctic Water which occurs in the subtropical convergence (Weber, 1994).

The hydrology of the Rio de Janeiro coast between Cabo Frio and Ponta de Joatinga (southern Rio de Janeiro State) is related mainly to the intensity and variability of the upwelling process, which is greatest between Cabo Frio Island and Saquarema Lagoon. The prevailing winds are east-to-west as a consequence of the Coriolis force. This causes drift of the superficial coastal water towards the ocean, which is equalized by the elevation of the South Atlantic Central Water coming from the continental slope between 200 and $300 \mathrm{~m}$.

The process of downwelling, which represents the return of warm and more saline waters of the Brazil Current to the coast, occurs during the passage of cold fronts with southwesterly winds. In winter, the hydrological structure is typical of downwelling, with a homothermic water column down to $50 \mathrm{~m}$. Homothermy with cold water is more common in spring and in some summer months, due to the maximum upwelling of the cold South Atlantic Central Water. With intensive upwelling, the surface temperature of the ocean can reach between 13 and $18^{\circ} \mathrm{C}$, and $5^{\circ} \mathrm{C}$ lower between 20 and $30 \mathrm{~m}$. More details of the physical-chemical conditions and the influence of upwelling in the area can be found in Weber (1994).

\section{SYSTEMATIC DESCRIPTIONS}

Suborder Podocopina Sars, 1866

Superfamily Cytheracea Baird, 1850

Family Cytheruridae Müller, 1894

Genus Hemicytherura Elofson, 1941
Hemicytherura auriculata sp. nov.

(Plate 1, figs 1-13)

1979 Hemicytherura howei (Puri) Sanguinetti: 135 and 136, pl. 5, figs $1 \mathrm{a}, 1 \mathrm{~b}, 1 \mathrm{c}$.

1985 Hemicytherura howei (Puri) Kotzian \& Eilert: 84-86 and 90 , pl. 1, figs 2,3 .

[non] 1953 Kangarina howei Puri: 246-247, pl. 4, fig. 7, text-figs $6 \mathrm{i}$ and $\mathrm{j}$.

[non] 1965 Hemicytherura howei (Puri) Pooser: 49, pl. 9, figs 1, 3. [non] 1979 Cytherura howei (Puri) Cronin: 144 and 145, pl. 14, fig. 7 .

Derivation of name. $L$. from the rather ear-like aspect of the right valve of this species in lateral view.

Diagnosis. Carapace with the right valve ear-like in lateral view and ornamentation formed by coarse and rounded reticulae. Large median rib that is interrupted medianly.

Holotype. Carapace, MP-O-1490.

Paratypes. Carapace, MP-O-1491.

Material. Nineteen adult valves and five juvenile valves.

Type locality. Rio de Janeiro coast, GEOCOSTA RIO II, sample 46. Age. Recent.

Description. Thick-shelled carapace, right valve ear-like in lateral view. Anterior margin angular and quadridentate. Apex below mid-height. Ventral margin with a distinct oral concavity. Posterior margin bluntly caudate in right valve, less pronounced in left valve. Dorsal margin strongly convex in right valve and stronger than in left valve. Ornament strongly reticulate, formed by circular reticulae. Dorsal region delicately punctate. Large median rib interrupted by reticulate ornament medianly. Two strong ventral ribs extend from the mid-anterior margin, parallel to the ventral margin. Two prominent depressions: one anteroventral and another postero-ventral occur below the median rib. Internal features typical of the genus. Sexual dimorphism not evident. 

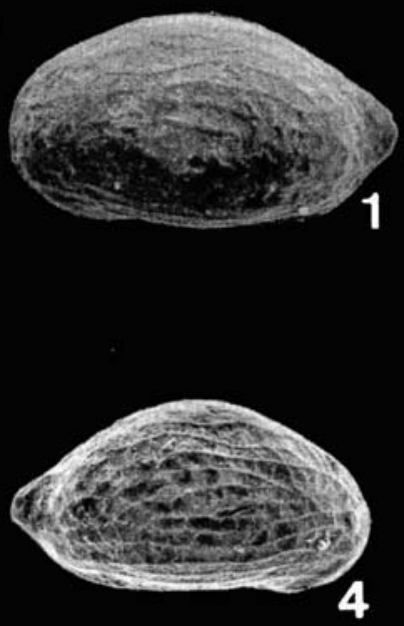

4

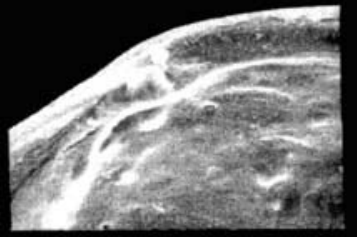

7

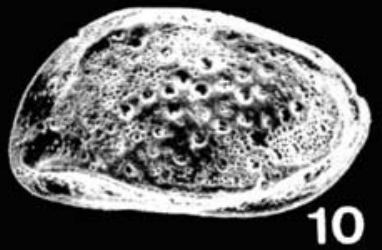

10

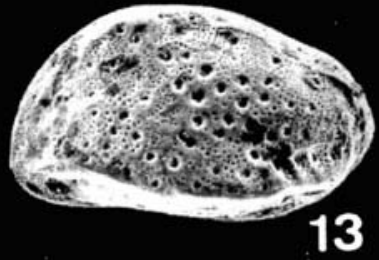

13
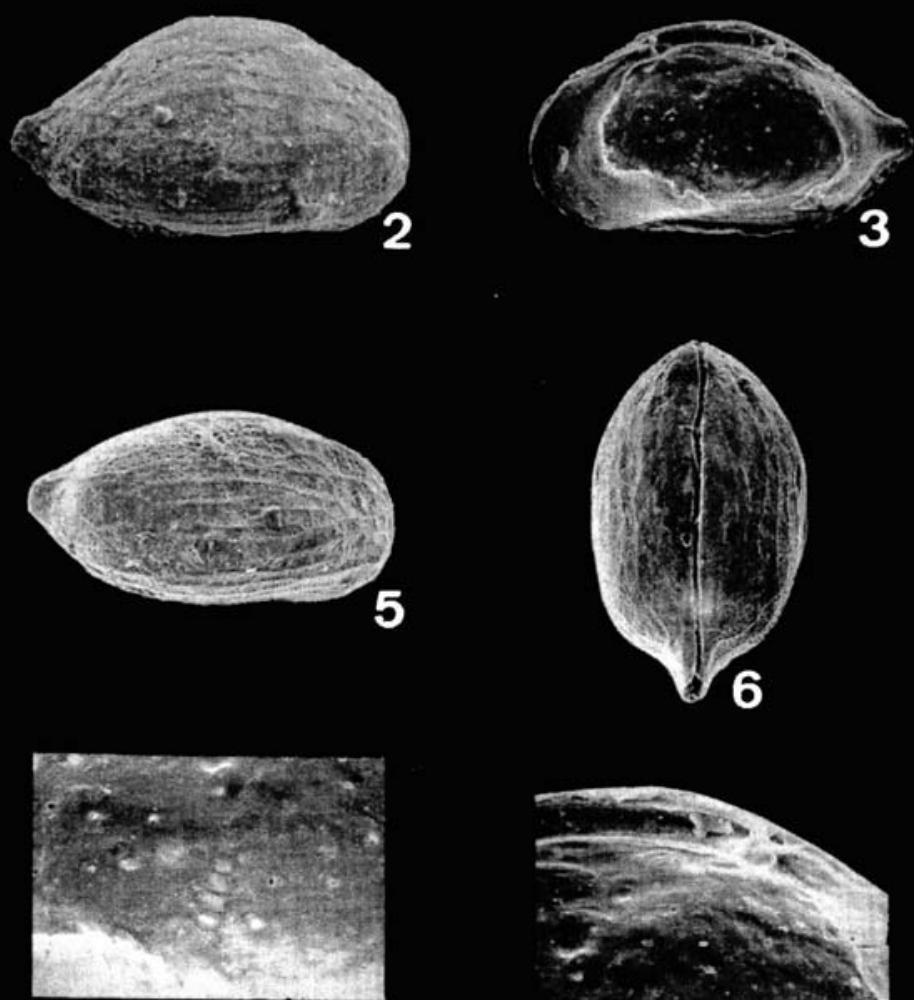

8
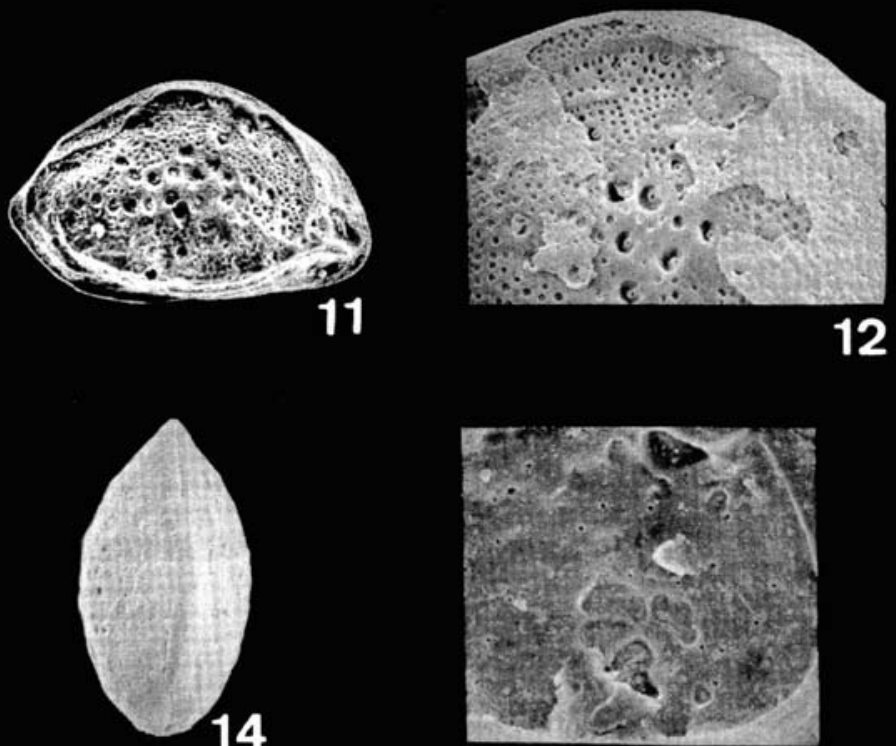

15

Explanation of Plate 2

figs 1-9. Semicytherura caudata sp. nov. figs 1-3, 7-9. Holotype. MP-O-1493, female. fig. 1. LV, external view, $\times 83$ fig. 2 . RV, external view, $\times 88$. fig. 3. $R V$, internal view, $\times 92$. fig. 4. Paratype. MP-O-1462, female, RV, external view, $\times 83$. fig. 5. Paratype. MP-O-1463, RV, male, external view, $\times 83$. fig. 6. Paratype. MP-O-1503, female carapace, dorsal view, $\times 88$. fig. 7. Holotype. RV, internal view, detail of anterior hinge, $\times 175$. fig. 8. Holotype. $\mathrm{RV}$, internal view, detail of muscle scars, $\times 175$. fig. 9. Holotype, RV, internal view, detail of posterior hinge, $\times 175$. figs 10-15. Oculocytheropteron delicatum sp. nov. figs 10, 11. Holotype. MP-O-1486, female. fig. 10. Holotype. LV, external view, $\times 92$. fig. 11. Holotype. RV, external view, $\times 92$. fig. 12. Paratype. MP-O-1492, RV, external view, detail of dorsal region, $\times 194$. fig. 13. Paratype. MP-O-1488, LV, external view, $\times 88$. fig. 14. Paratype. MP-O-1489, female, dorsal view, $\times 79$. fig. 15. Paratype. MP-O-1492, LV, internal view, detail of muscle scar, $\times 194$. 


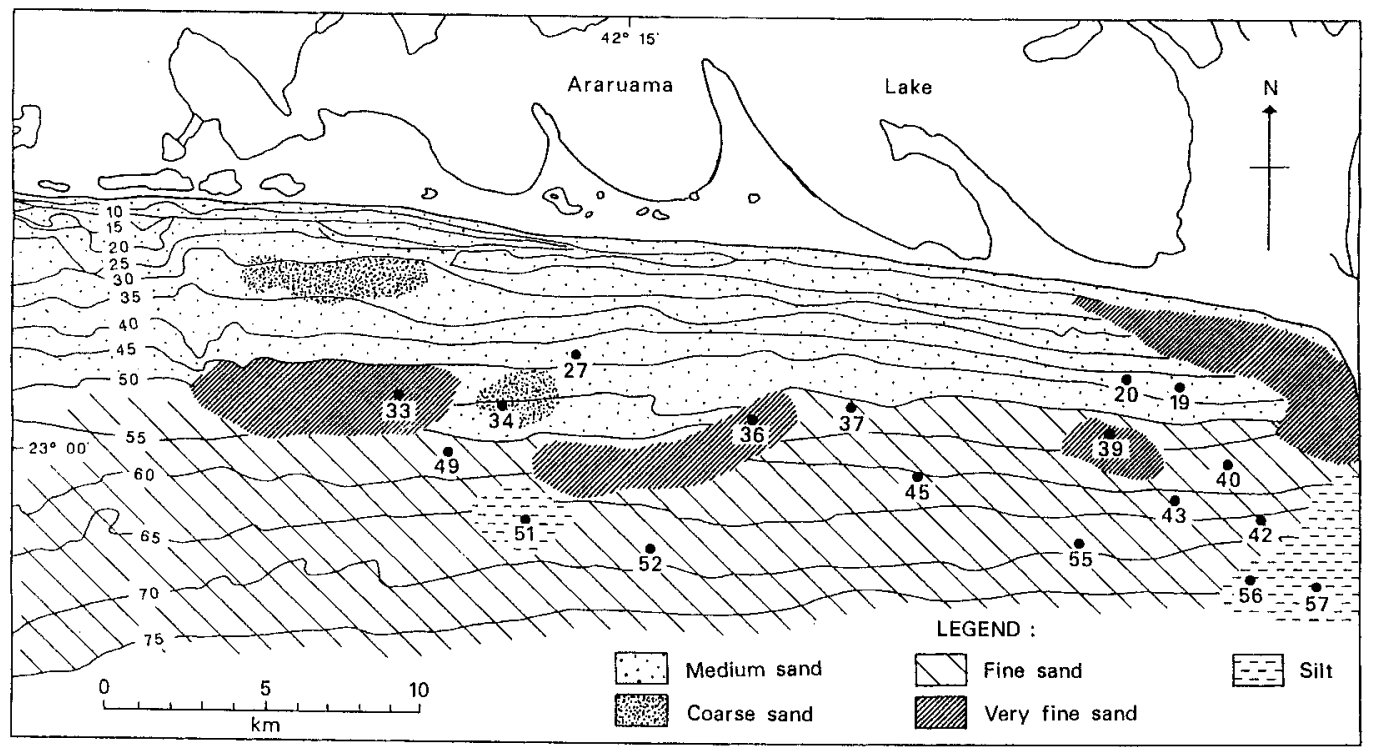

Fig. 4. Distribution of Semicytherura caudata sp. nov.

\section{Dimensions (mm) (length, height)}

Holotype, RV, MP-O-1490

Holotype, LV, MP-O-1490

Paratype, RV, MP-O-1491

Paratype, LV, MP-O-1491

0.51
0.51
0.46
0.44

0.35

0.33

0.32

0.28

Remarks. The present material is identical with Hemicytherura howei (Puri) (in Sanguinetti, 1979) from the Miocene of the Pelotas Basin. However, a comparative study of the present species with type material of Kangarina howei Puri, 1953, demonstrated that they are distinct species. Hemicytherura auriculata sp. nov. has less prominent ribs, the caudal process is shorter and straighter and it is bigger than Kangarina howei Puri, 1953. The species is known from the Miocene of the Pelotas Basin from Rio Grande do Sul (Brazil), the Miocene of Uruguay and from Recent sediments from Rio de Janeiro coast, GEOCOSTA RIO II, samples $33,46,47,48,49,51,52,53,55$ and 57 on fine sand and mainly between 51 and $72 \mathrm{~m}$ depth (Fig. 3).

Genus Semicytherura Wagner, 1957

Semicytherura rugosoreticulata Whatley, Chadwick, Coxill \& Toy, 1988.

(Plate 1, figs 14, 15)

1982 Kangarina sp. Kotzian (in Bertels, Kotzian \& MadeiraFalcetta): 146 and 149, pl. VII, fig. 1a, b.

1988 Semicytherura rugosoreticulata Whatley, Chadwick, Coxill \& Toy: 179 , pl. 2, figs $12-18$.

1990 Semicytherura rugosoreticulata Whatley, Chadwick, Coxill \& Toy. Bertels \& Martínez: 153, pl. 3, fig. 25.

Homotypes. Female, RV, MP-0-1500; male, RV, MP-0-1501. Age. Recent.

Material. Twenty-one adult valves and seven juvenile valves.

Dimensions (mm). (length, height)

Homotype, female, RV, MP-O-1500

0.45

0.25

Homotype, male, RV, MP-O-1501

0.47

0.23

Remarks. The present record is considerably further north than the records of Whatley et al. (1988), who found this species in the littoral zone of the Patagonian coast between $49^{\circ} 18^{\prime} \mathrm{S}$ and $42^{\circ} 47^{\prime} \mathrm{S}$, and also on the continental shelf north to $36^{\circ} 05^{\prime} \mathrm{S}$. It also occurs in the Quaternary of the Pelotas Basin, Chui Formation, Rio Grande do Sul State, Brazil; In the Holocene from Argentina; and in Recent sediments from the Rio de Janeiro coast, GEOCOSTA RIO II, samples 20, 27, 33, 36, 37, 39, 40, $42,43,45,46$ and 51. It occurs in depths up to $13 \mathrm{~m}$ in Recent sediments from Argentina and in the present study is distributed between 47 and $72 \mathrm{~m}$, being more abundant between 43 and $57 \mathrm{~m}$. It occurs predominantly in fine sands and, more rarely, in very fine and medium sands (Fig. 7).

Semicytherura caudata sp. nov.

(Plate 2, figs 1-9)

1982 Cytherura sp. Bertels, Kotzian \& Madeira-Falcetta: 131, 144-146, pl. 6, fig. 2a-c.

Derivation of name. $L$. with reference to the prominent caudal process.

Diagnosis. A subovate species of Semicytherura with large and upturned caudal process above mid-height in RV. Dorsal margin strongly arched. Ornament consists of numerous sinuous parallel horizontal ribs with short interconnecting riblets in the dorsal region. Finely punctate between the ribs.

Holotype. Female, carapace, MP-O-1493.

Paratype. Female, carapace, MP-O-1503; female, RV, MP-01462; and male, RV, MP-0-1463. 

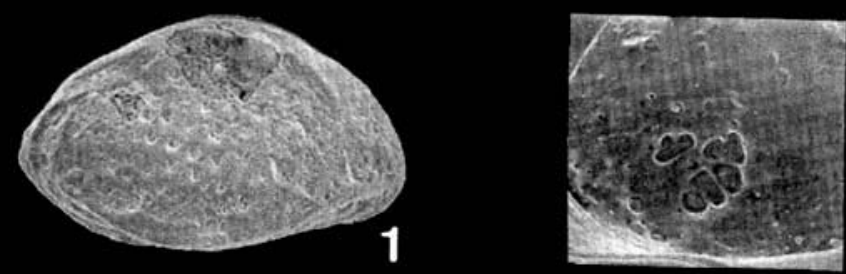

2
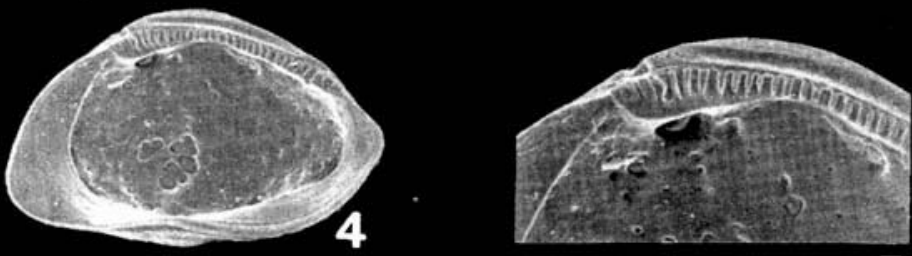

5

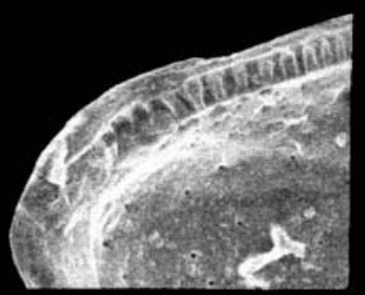

7

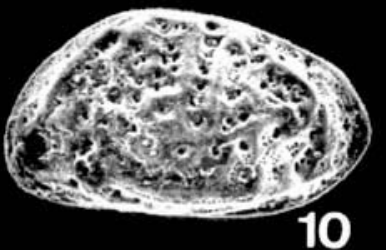

10

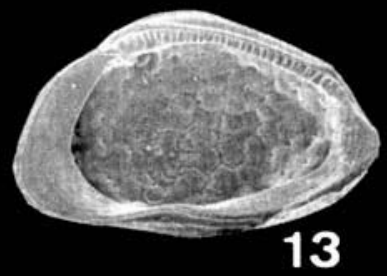

\section{8}
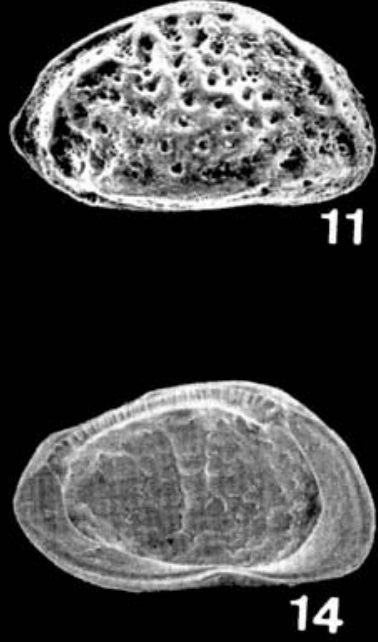
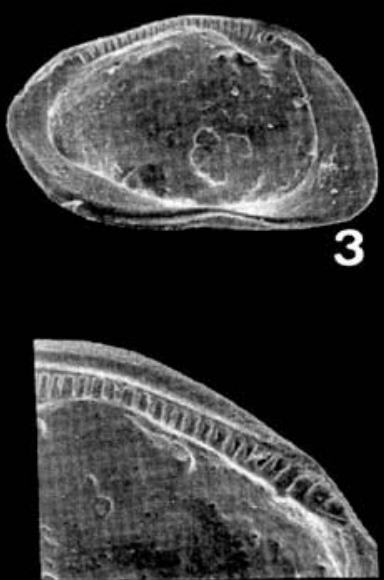

6
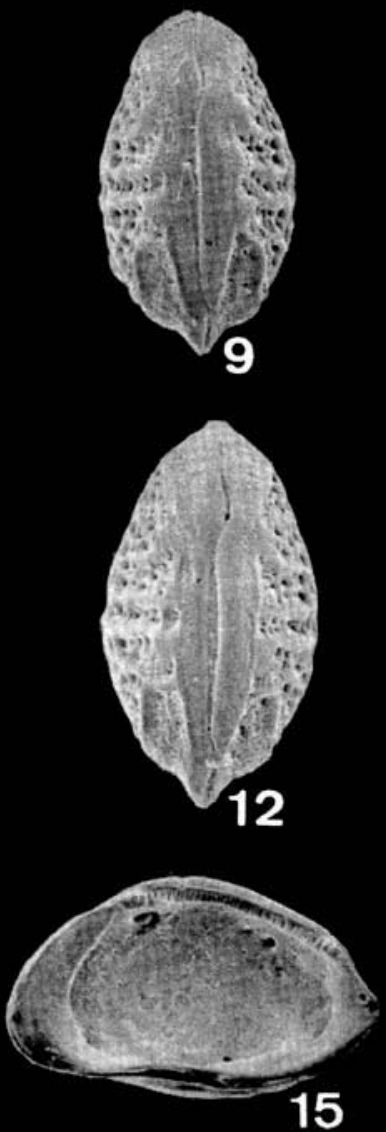

Explanation of Plate 3

figs 1-8. Oculocytheropteron delicatum sp. nov. fig. 1. Paratype. MP-O-1487, RV, male. figs 2-6. Holotype. MP-O-1486, female. fig. 1. Paratype. RV, external view, $\times 91$. fig. 2. Holotype. RV, internal view, detail of muscle scar, $\times 408$. fig. 3. Holotype. LV, internal view, $\times 92$; fig. 4. Holotype. RV, internal view. X107; fig. 5. Holotype, RV, internal view, detail of anterior hinge, $\times 500$. fig. 6. Holotype. RV, internal view, detail of posterior hinge, $\times 500$. fig. 7. Paratype. MP-O-1492, LV, internal view, detail of posterior hinge, $\times 301$. fig. 8. Paratype. MP-O- 1492 , LV, internal view, detail of anterior hinge, $\times 246$. figs 9-15. Oculocytheropteron circumcostatum sp. nov. fig. 9. Paratype. MP-O-1496, female, carapace, dorsal view, $\times 88$. figs 10, 11, 13, 14. Holotype. MP-O-1495, female. fig. 10. LV, external view, $\times 90$. fig. 11. RV, external view, $\times 97$. fig. 12. Paratype. MP-O-1497. Male, carapace, dorsal view. $\times 96$. figs 13, 14. Holotype. MP-O-1495, female. fig. 13. RV, internal view, $\times 97$. fig. 14. LV, internal view, $\times 90$. fig. 15. Paratype. MP-O-1498, RV, internal view, $\times 96$. 
Material. Eighty-three adult valves and seven juvenile valves. Type locality. Rio de Janeiro coast, GEOCOSTA RIO II, sample 43. Age. Recent.

Description. Carapace inflated, thin-shelled and subovate in lateral view. Slightly inequivalve. Cardinal angles not prominent; a few specimens are more accentuated in the posterior region. Anterior margin rounded. Posterior margin with large and upturned caudal process above mid-height in RV. Dorsal margin strongly arched. Ventral margin sinuous and slightly concave in the antero-median region. Ornament consists of sinuous parallel horizontal ribs interconnected with short riblets in the dorsal region. A median rib curves dorsally, almost forming a posterior loop. Internal features as for genus. Sexual dimorphism strongly developed, males more elongate and more

trically rounded. Posterior caudal process bluntly pointed in the left valve, slightly upturned in the right valve. Arched dorsal margin, much less strongly in the male than in the female. Ventral margin strongly overhung in the female, much less than in the male. Prominent eye spot. Valve surface with large rounded, well-spaced central puncta and much finer puncta peripherally. Delicate dorsal rib paralleling margin. Small postero-dorsal rib and distinct ventral rib extend from the postero-median region to the antero-ventral region. Internal features as for the genus. Sexual dimorphism not strongly marked.

\section{Dimensions (mm). (length, height)}

Holotype, female, RV, MP-O-1486 Holotype, female, LV, MP-O-1486 Paratype, male, RVMP-O-1487

Paratype, male, LV, MP-O-1487

Paratype, male, LV, MP-O-1488

Paratype, female, carapace, MP-O-1489

Paratype, female, RV, MP-O-1492

Paratype, female, LV, MP-O-1492

$\begin{array}{ll}0.38 & 0.24 \\ 0.38 & 0.22 \\ 0.38 & 0.22 \\ 0.39 & 0.22 \\ 0.40 & 0.27 \\ 0.41 & 0.27 \\ 0.41 & 0.25 \\ 0.41 & 0.26\end{array}$
inflated than females.

\section{Dimensions (mm). length, height}

0.45

0.45

0.42

0.42
Holotype, female, carapace, MP-O-1493

Paratype, female, carapace, MP-O-1503

\subsection{2}

0.22

0.23

Paratype, male, RV, MP-0-1463
Remarks. This species is similar to Hemicytherura chuiensis Kotzian (in Bertels, Kotzian \& Madeira-Falcetta, 1982) from the Quaternary of Rio Grande do Sul. However, it differs in that the puncta of the central area are much more spaced and fewer in number, and the ventral rib is more convex in the posterior region. It occurs along the Rio de Janeiro coast, GEOCOSTA RIO II, in samples $20,22,23,27,33,35,36,37,39,40,42,43,45,46,47$, $48,49,51,52,53,54,55,56$ and 57 at depths ranging between 40 and $72 \mathrm{~m}$, and mainly on fine sand sediments (Fig. 3).

\section{Oculocytheropteron circumcostatum sp. nov. (Plate 3, figs 9-15, Plate 4, figs 1-7)} GEOCOSTA RIO II, samples $18,20,27,28,33,36,37,39,40,41,42$, 43, 45, 46, 47 and 48. Semicytherura caudata sp. nov. is more numerous than either Hemicytherura auriculata or Semicytherura rugosoreticulata in the studied area. It is distributed between 42 and $72 \mathrm{~m}$ depth and is most abundant in medium sand. However, it is also found more rarely on very fine sands (Fig. 4).

Genus Oculocytheropteron Bate, 1972

Oculocytheropteron delicatum sp. nov.

(Plate 2, figs 10-15; Plate 3, figs 1-8)

Derivation of name. $L$. with reference to the delicately ornate carapace of this species.

Diagnosis. Oculocytheropteron with subovate right valve and subtrapezoidal left valve. Fragile, with coarse central and fine peripheral punctation and marginal ribs.

Holotype. Female, carapace, MP-O-1486.

Paratypes. Male, carapace, MP-O-1487; male, LV, MP-O-1488; female, carapace, MP-O-1489; and carapace, female, MP-O1492.

Material. Two hundred and thirty-four adult valves and 113 juvenile valves.

Type locality. Rio de Janeiro coast, GEOCOSTA RIO II, sample 33. Age. Recent.

Description. Small, fragile, sub-oval right valve and subtrapezoidal left valve in lateral view. Anterior margin asymme-
1975 Hemicytherura aff. Cytherura lilljeborgii Brady, 1880. Bertels: 335, pl. 5, fig. 16.

1988 Hemicytherura sp. Dias-Brito, Moura \& Würdig: p. 10, 11, pl. 2, fig. 38 .

Derivation of name. $L$. due to the strong sub-marginal rib.

Diagnosis. Small, subovate, thick-shelled. Valve surface coarsely punctate to almost reticulate and with two short vertical oblique parallel ribs extending over the dorso-median surface. A marginal anterior and posterior ribs running parallel to the margin.

Holotype. Female, carapace, MP-O-1495.

Paratypes. Female, carapace, MP-O-1496; male, carapace, MPO-1497; and female, carapace, MP-O-1498.

Material. Two hundred and thirty-four adult valves and one juvenile valve.

Type locality. Rio de Janeiro coast, GEOCOSTA RIO II, sample 33. Age. Recent.

Description. Small, subovate and thick-shelled. Anterior margin asymmetrically rounded with apex below mid-height. Posterior slightly caudate in the right valve, rounded in the left valve. Arched dorsal margin, most strongly in the female and in the right valve. Ventral margin slightly overhung in the female, much less so in the male. Eye spot is not evident. Valve surface coarsely punctate to almost reticulate; tiny secondary puncta; 

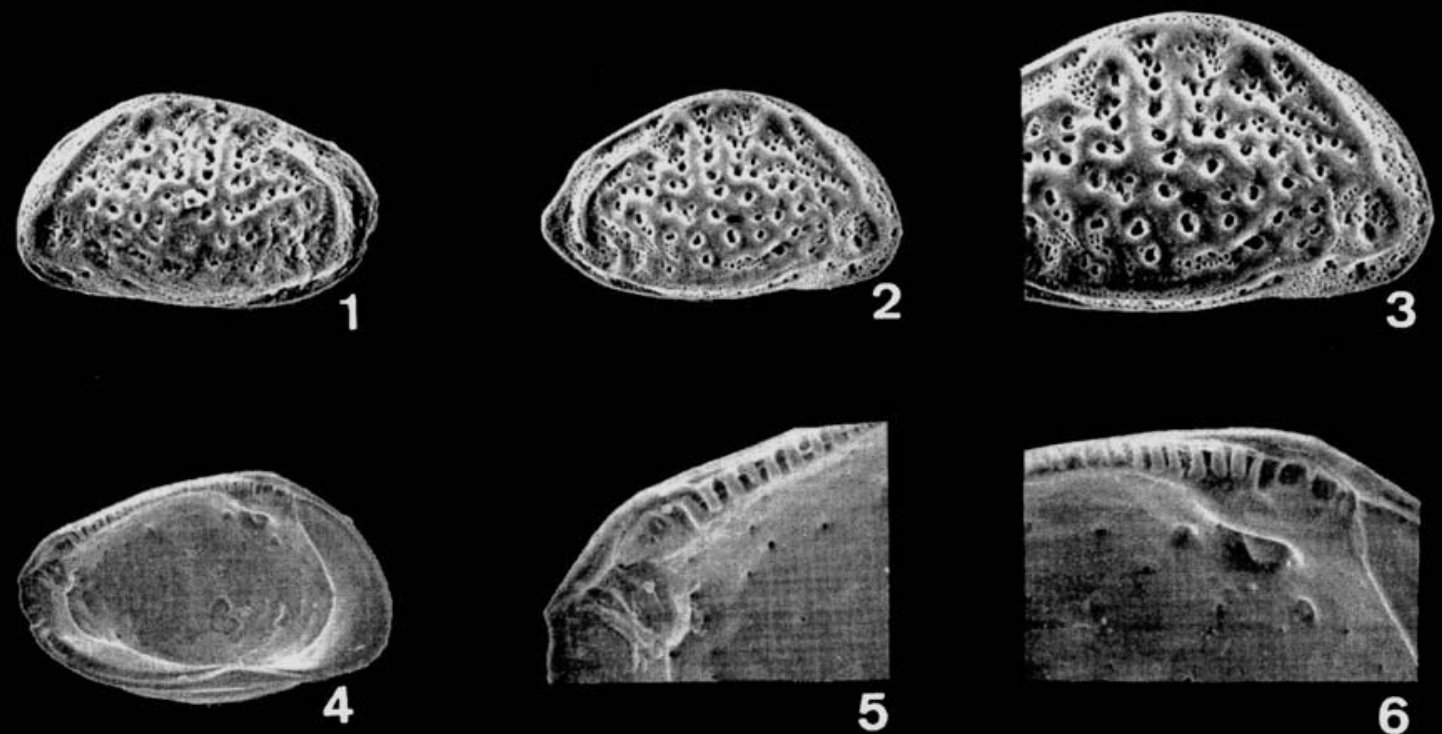

5
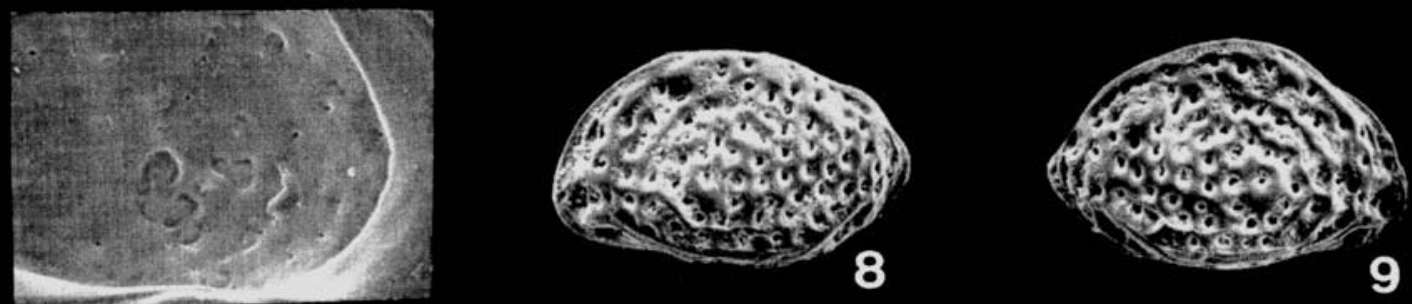

7
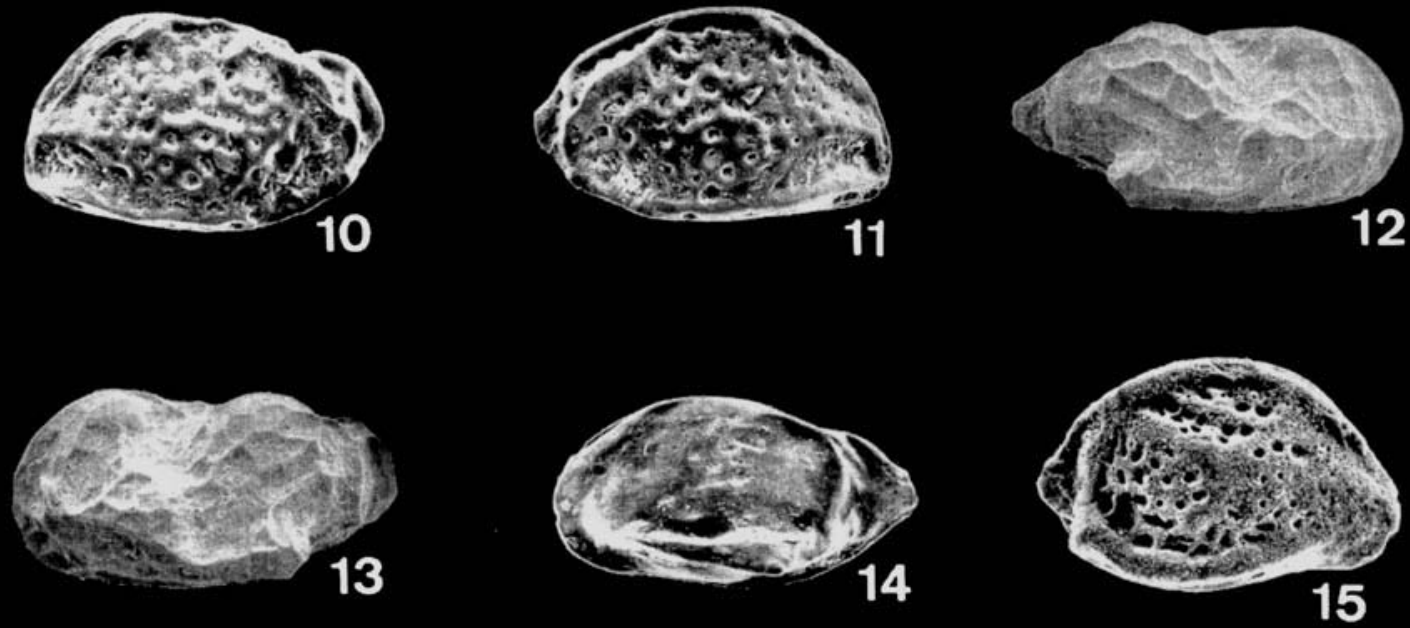

Explanation of Plate 4

figs 1-7. Oculocytheropteron circumcostatum sp. nov. Paratype. MP-O-1498, female. fig. 1. LV, external view, $\times 89$. fig. 2. RV, external view, $\times 85$. fig. 3. RV, external view, detail of anterior region, $\times 131$. fig. 4. LV, internal view, $\times 98$. fig. 5. LV, internal view, detail of posterior hinge, $\times 263$. fig. 6 . LV, internal view, detail of anterior hinge, $\times 263$. fig. 7 . LV, internal view, detail of muscle scar, $\times 194$. figs 8, 9. Oculocytheropteron macropunctatum Whatley, Chadwick, Coxill \& Toy, 1988. Homotype. MP-O-1494, female. fig. 8. LV, external view, $\times 74$. fig. 9. RV, external view, $\times 77$. figs 10, 11. Oculocytheropteron reticulopunctatum Whatley, Chadwick, Coxill \& Toy, 1988. Homotype. MP-O-1499, female. fig. 10. LV, external view, $\times 85$. fig. 11. RV, external view, $\times 81$. figs 12, 13. Paracytheridea bulbosa Purper \& Ornellas, 1989. fig. 12. Homotype. MP-O-1484. RV, female, external view, $\times$ 48. fig. 13. Homotype. MP-O-1485, LV, male, external view, $\times$ 48. fig. 14. Cytheropteron $s p$. Hypotype. MP-O-1502, LV, external view, $\times 54$. fig. 15 . Kangarina sp. Hypotype. MP-O-1483, RV, external view, $\times 116$. 


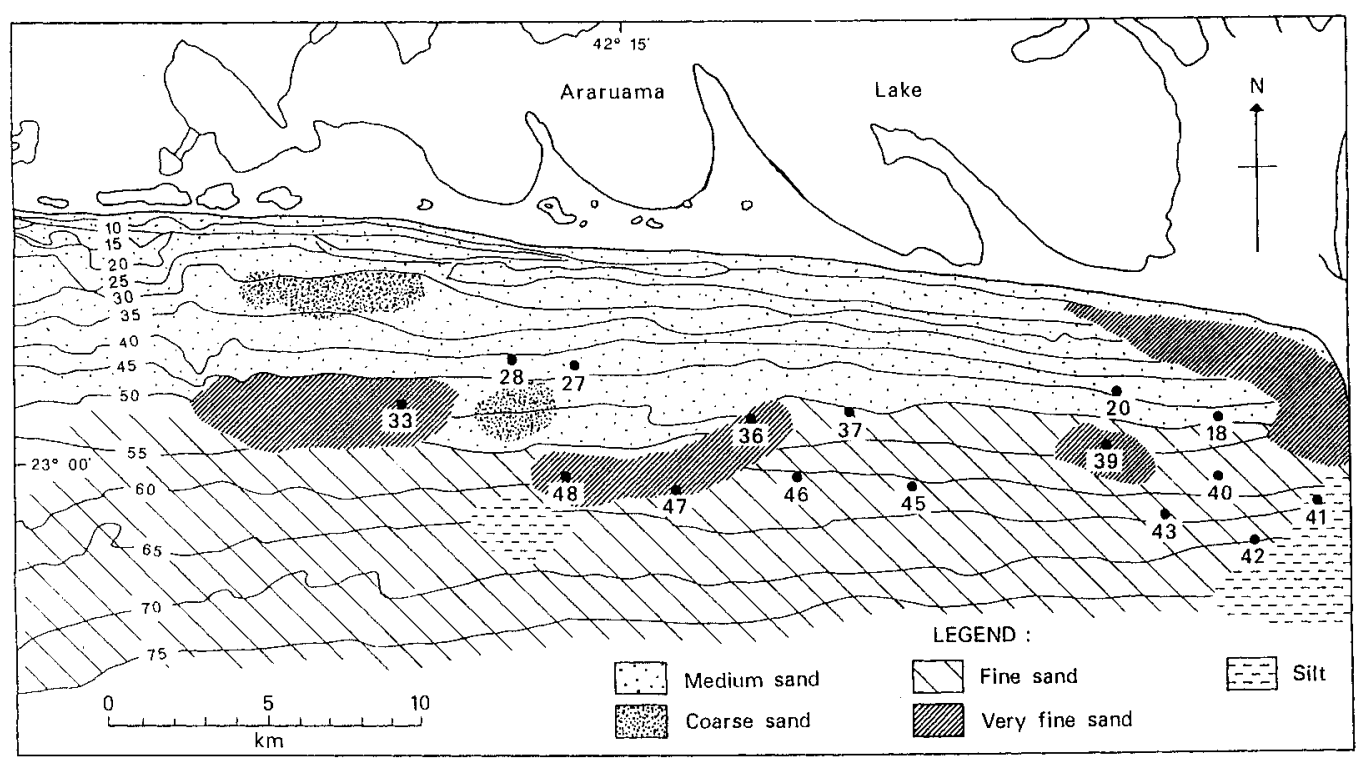

Fig. 5. Distribution of Oculocytheropteron circumcostatum sp. nov.

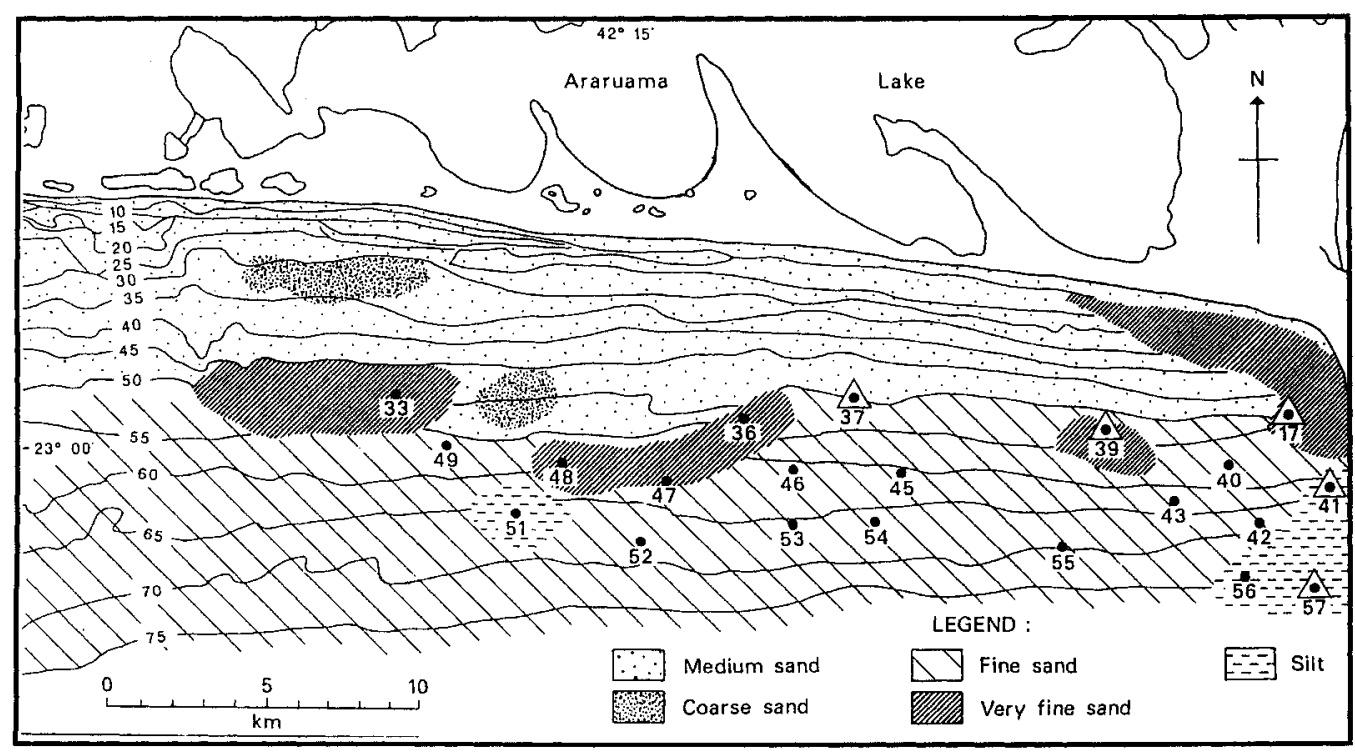

Fig. 6. Distribution of Oculocytheropteron macropunctatum Whatley et al., 1988 and $O$. reticulopunctatum Whatley et al., 1988. $\triangle$, Occurrence of $O$. macropunctatum, only. $\bullet$, Occurrence of both $O$. macropunctatum and $O$. reticulopunctatum.

small parallel oblique vertical ribs formed from the muri in the middle dorsal region; small postero median rib, parallel to caudal process. A strong rib borders the periphery of the carapace. Internal features as for the genus. Sexual dimorphism not strongly marked, male more elongated than the female.

\section{Dimensions (mm). (length, height)}

Holotype, female, RV, MP-O-1495

Holotype, female, LV, MP-O-1495

Paratype, female, RV, MP-O-1496

0.36

0.37

0.39
Paratype, female, LV, MP-O-1496

Paratype, male, RV, MP-O-1497

Paratype, male, LV, MP-O-1497

Paratype, female, RV, MP-O-1498

Paratype, female, LV, MP-O-1498

$\begin{array}{ll}0.39 & 0.24 \\ 0.41 & 0.22 \\ 0.41 & 0.22 \\ 0.41 & 0.24 \\ 0.39 & 0.24\end{array}$

Remarks. Oculocytheropteron circumcostatum sp. nov. is clearly the same species as Hemicytherura aff. Cytherura lilljeborgii Brady (in Bertels, 1975) from the Quaternary of Argentina. It occurs in the Pleistocene of Argentina (Buenos Aires Province) and the Recent of the Rio de Janeiro coast, GEOCOSTA RIO II, in 


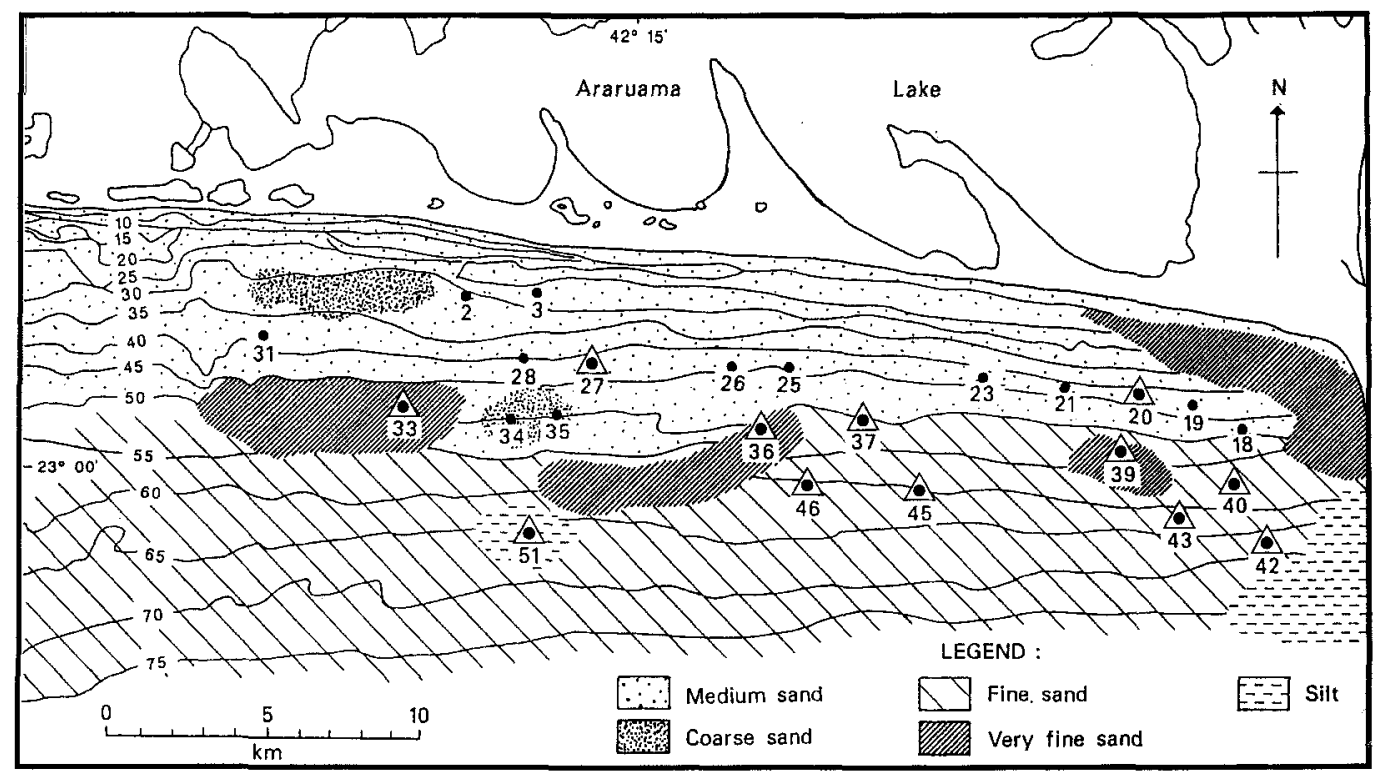

Fig. 7. Distribution of Paracytheridea bulbosa Purper \& Ornellas, 1989 and Semicytherura rugosoreticulata Whatley et al., 1988. $\triangle$, Occurrence of $S$. rugosoreticulata, only. •, Occurrence of both S. rugosoreticulata and Paracytheridea bulbosa.

samples $19,20,27,33,34,36,37,39,40,42,43,45,49,51,52$, 55,56 and 57 , with a bathymetric distribution between 42 and $74 \mathrm{~m}$, being more abundant between 51 and $72 \mathrm{~m}$. It prefers fine and very fine sandy sediments (Fig. 5).

Oculocytheropteron macropunctatum Whatley, Chadwick, Coxill \& Toy, 1988

(Plate 4, Figs 8, 9)

1977 Hemicytherura sp. Vicalvi, Kotzian \& Forti-Esteves: 83, 90, 91, pl. 3, fig. 5 .

1988 Oculocytheropteron macropunctatum Whatley, Chadwick, Coxill \& Toy: 184-188, pl. 4, figs 6-10.

Homotype. Female, carapace, MP-0-1494.

Age. Recent.

Material. One thousand one hundred and thirty-eight adult valves and 489 juvenile valves.

\section{Dimensions (mm). (length, height)}

Homotype, female, RV, MP-O-1494

Homotype, female, LV, MP-O-1494

Remarks. The present material is identical to Hemicytherura sp. of Vicalvi et al. (1977) described from the Quaternary of the São Paulo coast. The species occurs in the Quaternary of Argentina and southern Brazil, between $52^{\circ} 15.8^{\prime} \mathrm{S}$ and $24^{\circ} 2^{\prime} \mathrm{S}$; Pleistocene sediments from the coast of São Paulo State, Brazil and in the area studied, GEOCOSTA RIO II, samples $17,33,36,37,39,40,41$, $42,43,45,46,47,48,49,51,52,53,54,55,56$ and 57 , where it has a bathymetric distribution between 50 and $74 \mathrm{~m}$ and occurs mainly in fine sand (Fig. 6). Whatley et al. (1988) found this species in samples of fine calcareous mud with algal debris and from $118 \mathrm{~m}$ on clean fine sand.

Oculocytheropteron reticulopunctatum Whatley, Chadwick,
Coxill \& Toy, 1988.

(Plate 4, figs 10, 11)

1988 Oculocytheropteron reticulopunctatum Whatley, Chadwick, Coxill \& Toy: 186, 187, pl. 5, figs 3-7.

1990 Hemicytherura chuiensis (Kotzian) Bertels \& Martínez: 156, pl. 3, fig. 23.

(Non) 1982 Hemicytherura chuiensis Kotzian (in Bertels, Kotzian \& Madeira-Falcetta): 145-147, pl.6, fig. 3a-c.

Homotype. Female, carapace, MP-0-1499.

Age. Recent.

Material. One hundred and sixty-one adult valves and 68 juvenile valves.

Dimensions (mm). (length, height)

Homotype, female, RV, MP-O-1499

Homotype, female, LV, MP-O-1499

$\begin{array}{ll}0.43 & 0.26 \\ 0.41 & 0.24\end{array}$

Remarks. The present material is identical to Hemicytherura chuiensis Kotzian (in Bertels \& Martínez, 1990) from the Quaternary of Argentina. It occurs in the Recent of Argentina from the northern coast of Tierra del Fuego (53 $\left.56^{\prime} \mathrm{S}\right)$ and also in littoral samples between $40^{\circ} 25^{\prime} \mathrm{S}$ and $38^{\circ}$ and on the shelf and in the estuary of the Río de La Plata between $42^{\circ} 23^{\prime} \mathrm{S}$ and $36^{\circ} 05^{\prime} \mathrm{S}$. In the present study it was recovered from Recent sediments from the coast of Rio de Janeiro, GEOcosTA RIO II, in samples $33,36,40,42,43,45,46,47,48,49,51,52,53,54,55$ and 56 with a depth range between 50 and $72 \mathrm{~m}$ on fine sand (Fig 7).

Genus Paracytheridea Müller, 1894

Paracytheridea bulbosa Purper \& Ornellas, 1989

(Plate 4, figs 12, 13) 


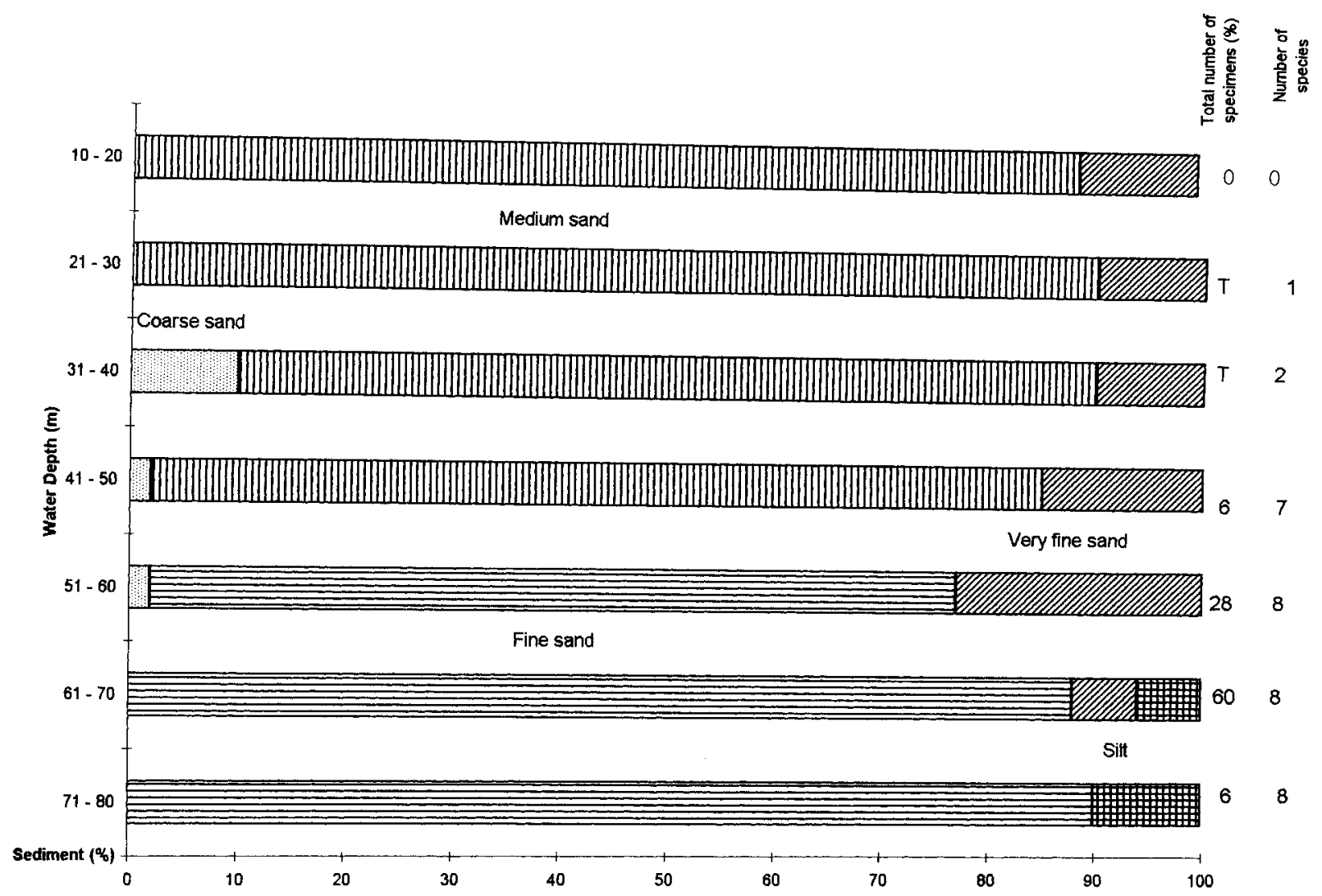

Fig. 8. Proportion of sediment types by depth $(\mathrm{T}<1 \%)$.

1988 Paracytheridea sp. Whatley, Chadwick, Coxill \& Toy: 191, 192, pl. 6, figs, 18.

1989 Paracytheridea bulbosa Purper \& Ornellas: 723, 724, pl. 2, figs $1-15$.

Homotype. Female, RV, MP-0-1484; male, LV, MP-0-1485.

Age. Recent.

Material. Eighty adult valves and 447 juvenile valves.

Dimensions (mm). (length, height)

Homotype, female, RV, MP-O-1484

Homotype, male, LV, MP-O-1485

$0.75 \quad 0.41$

$0.77 \quad 0.41$

Remarks. Whatley et al. (1988) found this species in a sample at $25 \mathrm{~m}$ off the coast of southern Brazil, $24^{\circ} 02^{\prime} \mathrm{S}, 45^{\circ} 43^{\prime} \mathrm{W}$. Purper \& Ornellas (1989) recorded it in the south of Brazil between $31^{\circ} 06^{\prime} \mathrm{S}$ and $22^{\circ} 01^{\prime} \mathrm{S}$. In the studied area, it occurred in GEOCOSTA RIO II, samples $2,3,18,19,20,21,23,25,26,27,28,31,33,34$, $35,36,37,39,40,42,43,45$ and 46 with a depth range between 27.5 and $74 \mathrm{~m}$ and a preference for medium sand (Fig. 7). Purper \& Ornellas (1989) found it at depths between 31 and $164 \mathrm{~m}$ in muddy, arenaceous, biodetritic sediments. Whatley et al. (1988) recorded it in shallower waters down to $25 \mathrm{~m}$, further south off the Argentinean coast.

Genus Cytheropteron Sars, 1866

Cytheropteron sp.

(Plate 4; fig. 14)
Hypotype. MP-O-1502, VD. GEO COSTA RIO II, sample 45 Age. Recent.

Material. Nine adult valves and seven juvenile valves.

Dimensions (mm). (length, height)

Hypotype, LV, MP-O-1502

0.64

0.44

Remarks. As a result of the small number of specimens found, this species is left in open nomenclature, although it is probably new. It occurs in samples $43,45,46,51,54,56$ and 57 , mainly on fine sand and silt and at depths between 57 and $74 \mathrm{~m}$.

Genus Kangarina Coryell \& Fields, 1937

Kangarina sp.

(Plate 4; fig. 15)

Hypotype. MP-O-1483, RV. GEO COSTA RIO II, sample 47.

Age. Recent.

Material. Five adult valves.

Dimensions (mm). (length, height)

Hypotype, RV, MP-O-1483

0.30

0.22

Remarks. This species is similar to Kangarina abyssicola Ruggieri, 1953 sensu Medeiros \& Coimbra, 1989. However, it differs in its less prominent ribs, its caudal apex being located nearer mid-height and in lacking a well-developed dorsal rib. As 


\begin{tabular}{|c|c|c|c|c|c|c|c|c|c|c|c|c|c|}
\hline Water Depth (m) / species (\%) & 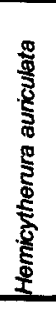 & 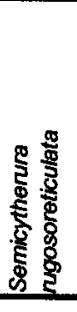 & 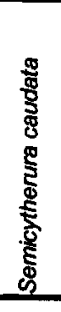 & 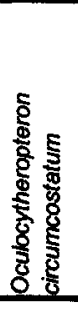 & 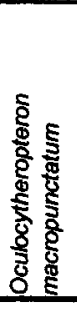 & 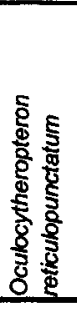 & 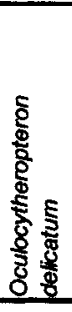 & 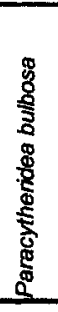 & 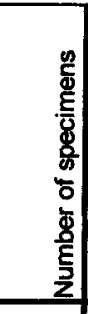 & 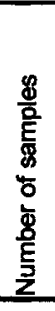 & $\begin{array}{l}\frac{8}{8} \\
8 \\
\frac{8}{8} \\
\frac{6}{0} \\
\frac{1}{8} \\
\frac{8}{E} \\
\frac{5}{2} \\
\end{array}$ & 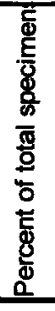 & 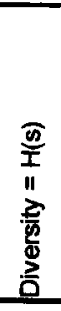 \\
\hline $10-20$ & - & - & - & - & - & - & - & - & - & - & - & - & - \\
\hline $21-30$ & 0 & 0 & 0 & 0 & 0 & 0 & 0 & 1 & 1 & 7 & 1 & $\mathbf{T}$ & 0 \\
\hline $31-40$ & 0 & 0 & 0 & 0 & 0 & 0 & 8 & 2 & 10 & 6 & 2 & $\mathrm{~T}$ & 0.27 \\
\hline $41-50$ & 0 & 4 & 20 & 25 & 12 & 3 & 11 & 53 & 128 & 13 & 7 & 6 & 1.5 \\
\hline $51-60$ & 5 & 5 & 45 & 102 & 314 & 23 & 65 & 20 & 579 & 7 & 8 & 28 & 1.4 \\
\hline $61-70$ & 16 & 10 & 16 & 87 & 817 & 123 & 167 & 3 & 1239 & 12 & 8 & 60 & 1.3 \\
\hline $71-80$ & 1 & 3 & 7 & 25 & 24 & 15 & 19 & 1 & 95 & 2 & 8 & 6 & 1.6 \\
\hline Total number of specimens & 22 & 22 & 88 & 239 & 1167 & 164 & 270 & 80 & 2052 & 47 & - & - & - \\
\hline \multicolumn{14}{|l|}{$0=a b s e n t$} \\
\hline _ = no data & & & & & & & & & & & & & \\
\hline$T=<1$ & & & & & & & & & & & & & \\
\hline
\end{tabular}

Table 1. Distribution of species by depth.

a result of the small number of specimens encountered, this species is left in open nomenclature, although it is probably new. The species occurred in samples 40,45 and 47 on fine sand and at depths of 55 and $62 \mathrm{~m}$. Owing to the rarity of both Kangarina sp. and Cytheropteron sp., distribution maps were not made for these species.

\section{DISCUSSION AND CONCLUSIONS}

Of the 47 samples studied, 36 yielded members of the Cytheruridae. The ten cytherurid species encountered belong to six genera: Hemicytherura, Semicytherura, Oculocytheropteron, Cytheropteron, Kangarina and Paracytheridea. Four new species are described: Hemicytherura auriculata, Sernicytherura caudata, Oculocytheropteron delicatum and Oculocytheropteron circumcostatum. Two species are left in open nomenclature, Kangarina sp. and Cytheropteron sp., because of the paucity of the specimens. Oculocytheropteron macropunctatum Whatley et al., 1988 and Oculocytheropteron reticulopunctatum Whatley et al., 1988, have previously been described from the Argentinean coast. Semicytherura rugosoreticulata Whatley et al., 1988 was described from the Recent of Patagonia and the Quaternary of Argentina and southern Brazil. Paracytheridea bulbosa Purper \& Ornellas, 1989 was previously recorded from southern Brazil. The distribution of the fauna clearly shows that most of the ostracods studied in this area have a preference for finer sands and greater depths offshore, where the influence of wave action on the bottom is diminished (Fig. 8).

The results show that ostracods are more abundant between 51 and $70 \mathrm{~m}$, where $88 \%$ of the total number of specimens occur (Table 1). Fine sand predominates in this depth range (Fig. 8).
The abundance of the fauna is inversely proportional to grain size and directly proportional to depth range. Only two samples were analysed between 71 and $80 \mathrm{~m}$, although the number of specimens found (95) in this depth range is considerably higher than from samples shallower than $51 \mathrm{~m}$ (Table 1, Fig. 8).

Between 20 and $40 \mathrm{~m}$, where medium sand predominates, few specimens occur (less than 1\%). Paracytheridea bulbosa and Oculocytheropteron delicatum occur in shallower water than other species; Paracytheridea bulbosa occurs in almost all samples with a large depth range, between 27.5 and $74 \mathrm{~m}$, but is more abundant between 45 and $51 \mathrm{~m}$ on medium and very fine sand. Although Oculocytheropteron delicatum occurs between 40 and $74 \mathrm{~m}$, it is more abundant between 60 and $70 \mathrm{~m}$. Semicytherura caudata and Oculocytheropteron circumcostatum are more abundant between 50 and $60 \mathrm{~m}$, where the sediment size ranges from medium to very fine sand (Figs 4 and 5, Table 1). Hemicytherura auriculata, Semicytherura rugosoreticulata, Oculocytheropteron macropunctatum and Oculocytheropteron reticulopunctatum are more abundant between 60 and $70 \mathrm{~m}$, in sediments of fine and very fine sands.

The highest diversity is between 71 and $80 \mathrm{~m}$, where the fauna is homogeneously distributed. The lowest diversity occurs between 20 and $30 \mathrm{~m}$, closer to the coast, where a single species is represented by only one specimen (Table 1). The highest number of specimens recovered, per genus, was for Oculocytheropteron. O. macropunctatum predominates over all other species and, together with $O$. delicatum, it has the highest percentage of constancy (Fig. 9).

Table 2 shows the number of specimens per species in each sample. The samples are listed in depth order. In Table $2, \mathrm{j}$ represents the presence of juveniles. Table 1 shows the 


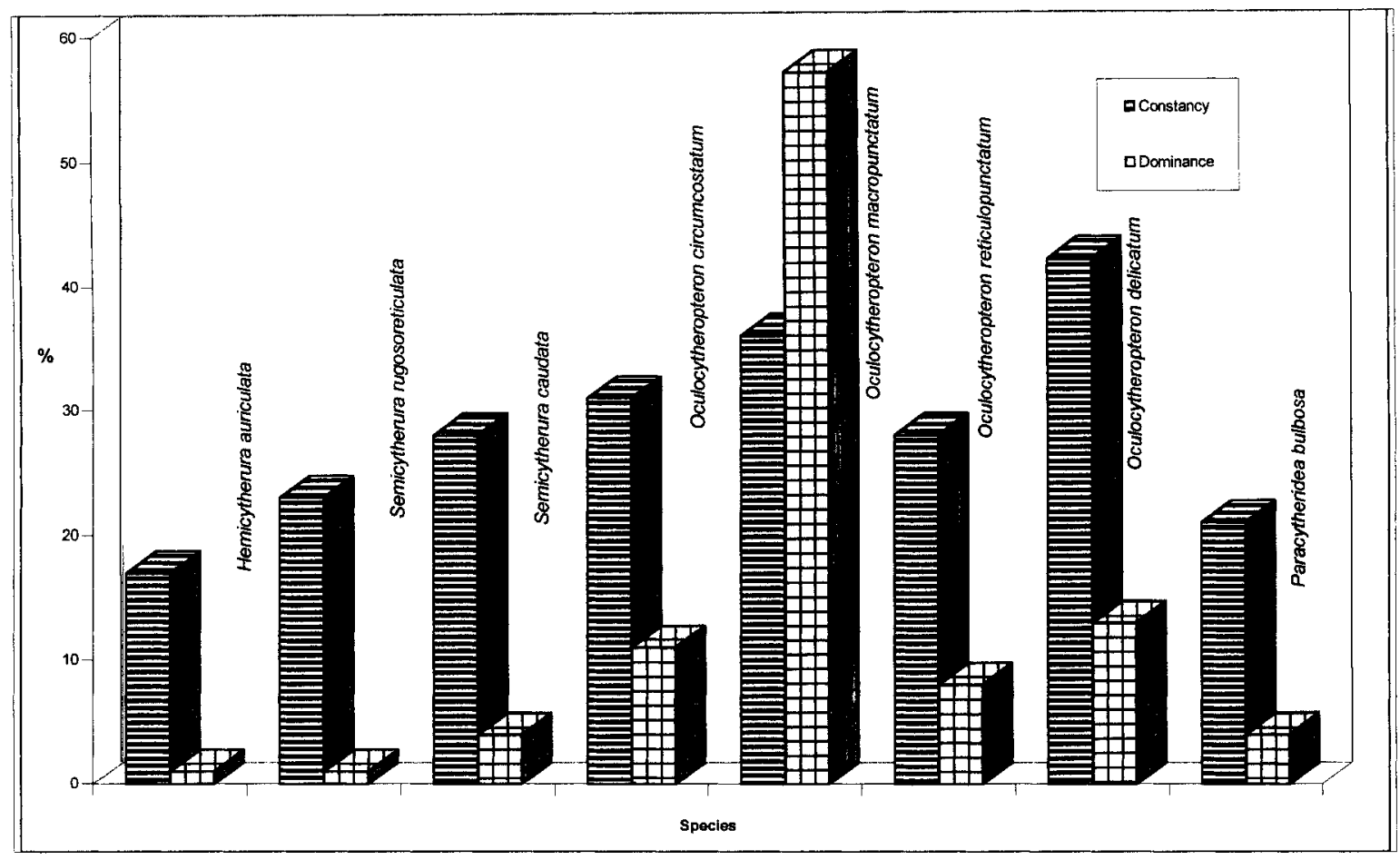

Fig. 9. Ostracod constancy and dominance.

distribution of species and the diversity of the fauna against depth, at $10 \mathrm{~m}$ intervals.

Many specimens exhibit dissolution and overgrowth of calcium carbonate. This can probably be explained by the effect of upwelling in this area. Normally, upwelled waters contain higher concentrations of nutrients (such as phosphates, silicates and nitrates) than surface water, which has been depleted as a result of biological consumption. Thus dissolution results from the corrosiveness of the water, due to a charge in the water's carbonate ion content, low temperature, and high hydrostatic pressure, increased water flow through the sediments and high $\mathrm{COO}_{2}$. Carbon dioxide in the water changes to carbonic acid, which eventually dissolves the calcium carbonate; carbon dioxide is produced by the respiration of benthonic organisms, which increases in upwelled waters (Kennet, 1982: 466).

Although dissolved and overgrown specimens might, in many circumstances, be thought to be the product of reworking of older sediments, in this area, given that the sediments are derived from the unfossiliferous Barreiras Group, this is considered unlikely.

The presence of Hemicytherura auriculata sp. nov., Semicytherura rugosoreticulata Whatley, Chadwick, Coxill \& Toy, 1988, S. caudata sp. nov., Oculocytheropteron macropunctatum Whatley, Chadwick, Coxill \& Toy, 1988, O. reticulopunctatum Whatley, Chadwick, Coxill \& Toy, 1988, O. circumcostatum sp. nov., $O$. delicatum sp. nov. and Paracytheridea bulbosa Purper \& Ornellas, 1989 (species having been recorded earlier as far south of the studied area as Uruguay and Argentina) can be explained by the presence of relatively cold waters due to the upwelling of the South Atlantic central water.

\section{ACKNOWLEDGEMENTS}

The authors thank the following persons from the Universidade Federal do Rio Grande do Sul (UFRGS): Cristianini Trescastro Bergue for laboratory support, Régis Lahm (Departamento de Geografia, Institututo de Geociências) for help with the Idrisi program for Windows, Professor Paul Potter for improving the manuscript and Eunice Meneguetti for the excellence of her artwork in producing the various maps. From Aberystwyth, we thank David Griffith and Geraint Hughes for their photographic skills and Anthony Smith for his excellent artwork. We also thank Alvin Phillips, Museum of Geology, Louisiana State University for allowing us to borrow the type material of Hemicytherura howei. We are particularly grateful to Dr Dieter Muhe, from the Departamento de Geografia of UFRJ, who allowed our study of the samples. The senior author is deeply indebted to Fundação de Amparo à Pesquisa do Estado do Rio Grande do Sul (FAPERGS) for a Post-MSc scholarship and the Conselho Nacional de Desenvolvimento Cientifico e Tecnologico (CNPq), which provided the grant to help her PhD study in Aberystwyth.

\section{Manuscript received 27 August 1996 \\ Manuscript accepted 28 January 1999}

\section{REFERENCES}

Bertels, A. 1975. Upper Cretaceous (Middle Maastrichtian) ostracodes of Argentina. Micropaleontology, 21(1): 97-130.

Bertels, A. \& Martínez, D. E. 1990. Quaternary ostracodes of continental and transitional littoral-shallow marine environments. Courier Forschungs-Institut Senckenberg, 123: 141-159.

Bertels, A., Kotzian, S. C. B. \& Madeira-Falcetta, M. 1982. Micro- 


\begin{tabular}{|c|c|c|c|c|c|c|c|c|c|c|}
\hline Sample & $\begin{array}{c}\text { Depth } \\
\text { (m) }\end{array}$ & $\mathbf{A}$ & $\boldsymbol{E}$ & $\mathbf{F}$ & $\mathbf{B}$ & c & $\mathbf{D}$ & $\mathbf{G}$ & H & Sediment \\
\hline 03 & 27,5 & & & & & & & & 1 & Medium sand, little organic material \\
\hline 02 & 30,5 & & & & & & & & $\mathrm{~J}$ & Medium sand, little organic material \\
\hline 22 & 40 & & & & & & & 1 & & Medium sand, little organic material \\
\hline 21 & 40 & & & & & & & & $\mathrm{~J}$ & Medium sand, organic material \\
\hline 23 & 42 & & & & & & & 1 & 1 & Medium sand, little organic material \\
\hline 19 & 42 & & & & & & 6 & & 1] & Medium sand, organic material \\
\hline 28 & 42 & & & & & 1 & & & 1 & Medium sand, organic material \\
\hline 20 & 43 & & & & 1 & 6 & 6 & 4 & 10j & Medium sand, little organic material \\
\hline 26 & 43,5 & & & & & & & & 3 & Medium sand, little organic material \\
\hline 25 & 45 & & & & & & & & 2 & Medium sand, little organic material \\
\hline 27 & 45,5 & & & & 1 & 6 & 2 & 5 & 19 & Medium sand, organic material \\
\hline 31 & 48 & & & & & & & & 4 & Medium sand, abundant organic material \\
\hline 34 & 49 & & & & & & 2 & & 3 & Coarse sand, shells, organic material \\
\hline 35 & 50 & & & & & & & 1 & $\mathbf{i}$ & Coarse sand, shells, organic material \\
\hline 18 & 50 & & & & & 1 & & & I & Medium sand \\
\hline 36 & 50 & & 2 & 4 & 2 & 6 & 8 & 1 & 7 & Very fine sand, abundant organic material \\
\hline 37 & 51 & & I & & 1 & 10 & 6 & 4 & 6 & Fine sand, organic material \\
\hline 33 & 51 & 2 & 18 & 6 & 1 & 8 & 48 & 17 & 20 & Very fine sand, organic material \\
\hline 17 & 53,5 & & 5 & & & & & & & Very fine sand \\
\hline 43 & 57 & & 116j & 5] & 2 & 22] & 27 & 23] & 1 & Fine sand, some shells \\
\hline 39 & 58 & & 25 & & 1 & 3 & 22 & 6 & 2 & Very fine sand, organic material \\
\hline 47 & 58 & 2 & 88] & 6] & & 1 & & 4 & & Very fine sand organic material \\
\hline 48 & 58 & 1 & 62j & 6 & & 1 & & 12 & & Very fine sand, organic material \\
\hline 49 & 60,5 & 6 & 94] & 7) & & & 1 & 19 & & Fine sand, organic material \\
\hline 40 & 61 & & 14] & 6 & 2 & 14 & 24 & 8] & $\mathrm{J}$ & Fine sand, organic material \\
\hline 45 & 62 & & 109j & 26] & 5 & 1 & 56 & $37 j$ & $j$ & Fine sand, polychaetes \\
\hline 46 & 62 & 4 & $203\}$ & 11 & 1 & 1 & & $30 \mathrm{j}$ & $\mathbf{I}$ & Fine sand, polychaetes \\
\hline 54 & 66 & & 39 & 5 & & & & I & & Fine sand \\
\hline 53 & 66 & 1 & $60 \mathrm{j}$ & 31] & & & & 4) & & Fine sand, little organic material \\
\hline 55 & 67 & 1 & $56 \mathrm{~J}$ & 9] & & & 2 & 6) & & Fine sand, little organic material \\
\hline 51 & 67 & 2] & 144 & 13! & 2 & & 2 & 63j & & Silt, organic material \\
\hline 52 & 68 & 2! & 97] & 15 & & & 5 & $5]$ & & Fine sand, little organic material \\
\hline 41 & 71 & & 8 & & & 1 & & & & Silt, little organic material \\
\hline 56 & 72 & & 4 & 6] & $\mathbf{j}$ & & 3 & J & & Silt, little organic material \\
\hline 57 & 72 & 1 & 8] & & & & 4 & 1 & & Silt, polychaetes \\
\hline 42 & 74 & & 14j & $8 j$ & 2 & 6] & 19] & 17] & $\mathrm{J}$ & Fine sand \\
\hline
\end{tabular}

Table 2. Samples with number of specimens per species, in depth order. A, Hemicytherura auriculata sp. nov.; B, Semicytherura rugosoreticulata Whatley et al., 1988; C, Semicytherura caudata sp. nov.; D, Oculocytheropteron circumcostatum sp. nov.; E, Oculocytheropteron macropunctatum Whatley et al., 1988; F, Oculocytheropteron reticulopunctatum Whatley et al., 1988; G, Oculocytheropteron delicatum sp. nov.; and $\mathrm{H}$, Paracytheridea bulbosa Purper \& Ornellas, 1989. j, presence of juveniles.

paleontología (foraminiferos y ostrácodos) del Cuaternario de Palmares do Sul (Formación Chuí), Brasil. Ameghiniana, 19(1-2): $125-156$.

Coimbra, J. C. \& Ornellas, L. P. 1989. Distribution and ecology of Subrecent Orionininae (Ostracoda) in the Brazilian Continental Shelf. Revista Brasileira de Geociências, 19(2): 177-186.

Coimbra, J. C., Ramos, M. I. F. \& Sanguinetti, Y. T. 1992. Sub-recent ostracodes of the Tamandare Bay, Northeastern Brazil - a preliminary report on biofacies. Pesquisas, 19(1): 95-105.

Cronin, T. M. 1979. Late Pleistocene marginal marine ostracodes from the Southeastern Atlantic Coastal Plain and their paleoenvironmental implications. Geogr. phys. Quat., 33(2): 121-173.

Dias-Brito, D., Moura, J. A. \& Würdig, N. 1988. Relationships between ecological models based on ostracods and foraminifers from Sepetiba Bay (Rio de Janeiro -- Brazil). In: Hanai, T., Ikeya, N. \& Ishizaki, K. (eds) Evolutionary Biology of Ostracoda: its Fundamentals and Applications. Proceedings of the 9th International Symposium on Ostracoda, Shizuoka, Japan. pp. 467-484.

Kennet, J. P. (ed.) 1982. Marine Geology. Prentice-Hall, Englewood Cliffs, 813 pp.

Kotzian, S. C. B. \& Eilert, V. P. 1985. Ostracodes Mio-Pleistocênicos da Perfuração Chuí no 364 . (Bacia de Pelotas), Uruguai. Acta Geologica Leopoldensia 9(20): 81-94.

Medeiros, M.A. \& Coimbra, J.C. 1989. Subrecent distribution of Kangarina Coryell \& Fields, 1937 (Crustacea; Ostracoda) in the northern Brazilian coast. In: Congresso Brasileiro de Paleontologia, I1,
Curitiba, Anais. Vol. 1. Sociedade Brasileva do Petroleo, Curitiba, 479-491.

Muehe, D. 1989. Distribuição e caracterização dos sedimentos arenosos da plataforma continental interna entre Niteroi e Ponta Negra, RJ. Revista Brasileira de Geociencias, 19(1): 25-36.

Muehe, D. \& Carvalho, V. G. de. Geomorfologia, cobertura sedimentar e transporte de sedimentos na plataforma continental interna entre a Ponta de Saquarema e o Cabo Frio. Boletim Institut Oceanografico São Paulo, in press.

Ornellas, L. P. \& Fallavena, M. A. 1978. Cytherura purperae Ornellas \& Fallavena, sp. nov. a living Ostracoda from mixohaline environment, southern Brazil. Pesquisas, 9: 121-157.

Pinto, I. D., Ornellas, L. P., Purper, I., Kotzian, S. B. \& Sanguinetti, Y. T. 1978. Recent ostracodes along $7.408 \mathrm{~km}$ of the Brazilian coast $\left(33^{\circ} 45^{\prime}\right.$ S to $\left.4^{\circ} 25^{\prime} \mathrm{N}\right)$. Pesquisas, 9: 109-120.

Pooser, W. K. 1965. Biostratigraphy of Cenozoic Ostracoda from South Carolina. The University of Kansas Paleontological Contributions, 8: 180.

Puri, H. S. 1953. Contribution to the study of the Miocene of the Florida Panhandle Part III. Ostracoda. Florida St. Board. Constitution Geological Bulletin, 36: 223-345.

Purper, I. \& Ornellas, L. P. 1987a. Paracytheridea tschoppi van den Bold, 1946 and its allied species, Paracytheridea batei Purper \& Ornellas, sp. nov. in the Brazilian continental shelf. In: Congresso Brasileiro de Paleontologia, 10, Rio de Janeiro, Anais. Vol. 1. Sociedade Brasileva do Petroleo, Rio de Janeiro, 747-759. 
Purper, I. \& Ornellas, L. P. 1987b. The genus Paracytheridea (Ostracoda) in the northern/northwestern Brazilian continental shelf. Pesquisas, 20: 103-124.

Purper, I. \& Ornellas, L. P. 1989. New species of Paracytheridea (Ostracoda) in the Brazilian continental shelf. In: Congresso Brasileiro de Paleontologia, 11, Curitiba, Anais. Vol. 1. Sociedade Brasileva do Petroleo, Curitiba, 721-732.

Sanguinetti, Y. T. 1979. Miocene ostracodes of the Pelotas Basin, State of Rio Grande do Sul, Brasil. Pesquisas, 12, 119-187.

Tinoco, I. M. (ed.) 1989. Introdução ao Estudo dos Componentes Bióticos dos Sedimentos Marinhos Recentes. Universitária da UFPE, Recife.
Vicalvi, M. A., Kotzian, S. C. B \& Forti-Esteves, I. R. 1977. A ocorrência de microfauna estuarina no Quaternário da Plataforma Continental de São Paulo. In: Projeto REMAC - Reconhecimento Global da Margem Continental Brasileira.Vol. 2. PETROBRAS, CENPES, DINTEP, Rio de Janeiro, 77-96.

Weber, R. R. (co-ord.). 1994. Diagnóstico ambiental oceânico e costeiro das regioes sul e sudeste do Brasil. Oceanografia química, 3: 254-263.

Whatley, R. C., Chadwick, J., Coxill, D. \& Toy, N. 1988. The ostracod Family Cytheruridae from the Antarctic and southwest Atlantic. Revista Española de Micropaleontología, 20(2): 171-203. 